\title{
Selective inhibition of prolyl 4-hydroxylases by bipyridinedicarboxylates
}

\section{James D. Vasta ${ }^{\mathrm{a}}$ and Ronald T. Raines ${ }^{\mathrm{a}, \mathrm{b}, *}$}

${ }^{\mathrm{a}}$ Department of Biochemistry and ${ }^{\mathbf{b}}$ Department of Chemistry, University of Wisconsin-Madison, Madison, Wisconsin 53706, United States

* Corresponding author. Tel.: 608262 8588; fax: 6088902583

E-mail address: rtraines@wisc.edu (R. T. Raines)

Keywords:

Collagen

$\alpha$-Ketoglutarate

Hydroxyproline

Hypoxia-inducible factor

Iron 


\section{ABSTRACT}

Collagen is the most abundant protein in animals. A variety of indications are associated with the overproduction of collagen, including fibrotic diseases and cancer metastasis. The stability of collagen relies on the posttranslational modification of proline residues to form $(2 S, 4 R)$-4-hydroxyproline. This modification is catalyzed by collagen prolyl 4-hydroxylases (CP4Hs), which are Fe(II)- and $\alpha$-ketoglutarate (AKG)-dependent dioxygenases located in the lumen of the endoplasmic reticulum. Human CP4Hs are validated targets for treatment of both fibrotic diseases and metastatic breast cancer. Herein, we report on 2,2'-bipyridinedicarboxylates as inhibitors of a human $\mathrm{CP} 4 \mathrm{H}$. Although most 2,2'-bipyridinedicarboxylates are capable of inhibition via iron sequestration, the 4,5'- and 5,5'-dicarboxylates were found to be potent competitive inhibitors of $\mathrm{CP} 4 \mathrm{H}$, and the 5,5'-dicarboxylate was selective in its inhibitory activity. Our findings clarify a strategy for developing $\mathrm{CP} 4 \mathrm{H}$ inhibitors of clinical utility. 


\section{Introduction}

Collagen is the principle component of bone, connective tissues, and the extracellular matrix in animals. ${ }^{1}$ A variety of diseases are associated with the overproduction of collagen, including fibrotic diseases (such as pulmonary fibrosis, renal fibrosis, and hepatic cirrhosis) ${ }^{2,3}$ and cancers. ${ }^{4-8}$ The stability of collagen relies on posttranslational modifications that occur throughout the secretory pathway. ${ }^{9}$ The most prevalent of these modifications is the hydroxylation of collagen strands by collagen prolyl 4-hydroxylases $\left(\mathrm{CP} 4 \mathrm{Hs}^{10}\right)$, which are $\mathrm{Fe}(\mathrm{II})$ - and $\alpha$-ketoglutarate (AKG)-dependent dioxygenases (FAKGDs) located in the lumen of the endoplasmic reticulum. ${ }^{11}$ Catalysis by CP4Hs converts $(2 S)$-proline (Pro) residues in protocollagen strands into $(2 S, 4 R)$-4-hydroxyproline (Hyp) residues (Figure 1), which are essential for the conformational stability of mature collagen triple helices. ${ }^{12}$ Importantly, CP4Hs are validated targets for treating both fibrotic diseases ${ }^{13}$ and metastatic breast cancer, ${ }^{7}$ which in aggregate represent a massive unmet clinical need.

Like all enzymes of the FAKGD superfamily, catalysis by CP4Hs requires Fe(II), which is bound by a conserved His-X-Asp/Glu... $\mathrm{X}_{\mathrm{n}} \ldots$ His motif, as well as the cosubstrates $\mathrm{AKG}$ and dioxygen. ${ }^{14}$ AKG chelates to enzyme-bound Fe(II) using its $\mathrm{C}-1$ carboxylate and $\mathrm{C}-2$ keto groups, while the C-5 carboxylate group engages in Coulombic interactions with a basic residue (typically arginine or lysine) and additional hydrogen bonds. All FAKGDs are believed to effect catalysis through a similar two-stage mechanism in which AKG is first oxidatively decarboxylated to generate a highly reactive $\mathrm{Fe}(\mathrm{IV})=\mathrm{O}$ species (ferryl ion), after which the ferryl ion interacts with a hydrocarbon substrate and effects hydroxylation via a radical rebound process. ${ }^{14}$ 
In vertebrates, $\mathrm{CP} 4 \mathrm{Hs}$ are known to exist as $\alpha_{2} \beta_{2}$ tetramers. In these tetramers, the $\alpha$-subunit contains the catalytic and substrate-binding domains, and the $\beta$-subunit is protein disulfide isomerase, which is a multifunctional protein that is responsible for maintaining the $\alpha$-subunit in a soluble and active conformation. ${ }^{11}$ Three isoforms of the $\alpha$-subunit, $\alpha(\mathrm{I}), \alpha(\mathrm{II})$, and $\alpha(\mathrm{III})$, have been identified in humans. ${ }^{11}$ All $\alpha$-subunit isoforms form tetramers with the $\beta$-subunit, which we refer to herein as the $\mathrm{CP} 4 \mathrm{H} 1, \mathrm{CP} 4 \mathrm{H} 2$, and $\mathrm{CP} 4 \mathrm{H} 3$ holoenzymes. As the most prevalent of the isoforms, the $\alpha(\mathrm{I})$-subunit has been characterized extensively. Whereas the structure of the tetrameric complex is unknown, those of individual domains of the $\alpha(\mathrm{I})$-subunit have provided insight into the manner in which $\mathrm{CP} 4 \mathrm{Hs}$ interact with the protocollagen substrate, as well as the means by which the $\alpha$-subunits dimerize to facilitate formation of the tetramer. ${ }^{15-17}$

The development of CP4H inhibitors has been of keen interest since the mid 1970s. Like many FAKGDs, human CP4Hs are inhibited by simple metal chelators, such as 2,2'-bipyridine (1), as well as AKG mimics (Figure 2), such as $N$-oxalyl glycine (2), pyridine-2,4-dicarboxylic acid (3a) and pyridine-2,5-dicarboxylic acid (3b). ${ }^{18}$ In general, simple metal chelators are thought to inhibit $\mathrm{CP} 4 \mathrm{Hs}$ by iron sequestration, as evidenced by $\mathrm{IC}_{50}$-values that are similar to the iron concentration used in assays in vitro. In contrast, $\mathrm{AKG}$ mimics are thought to bind competitively in the AKG binding site, using a chelating moiety to interact with the enzymic iron and an additional carboxyl group to form favorable Coulombic interactions with Lys493. ${ }^{18}$ Compounds of this nature typically display values of $\mathrm{IC}_{50}$ or $K_{\mathrm{i}}$ that are less than the value of $K_{\mathrm{m}}$ for $\mathrm{AKG}$ (which is $20 \mu \mathrm{M}$ for human $\mathrm{CP} 4 \mathrm{H} 1$ ). ${ }^{19}$ There are also examples of electrophilic AKG mimics such as coumalic acid ${ }^{20}$ and 4-oxo-5,6-epoxyhexanoic acid ${ }^{21}$ that appear to inhibit CP4H via covalent modification of the active site. Compounds of this nature could have intriguing chemical and biological utility. 
Of the simple AKG mimics, the most potent inhibitor of human $\mathrm{CP} 4 \mathrm{Hs}$ reported to date is $\mathbf{3 b}$, which was found to have a $K_{\mathrm{i}}=0.8 \mu \mathrm{M}$ and display modest selectivity for human CP4Hs compared to other FAKGDs, such as the prolyl hydroxylase domain-containing proteins (PHDs), factor-inhibiting HIF (FIH), and Jumonji domain-containing 2E (JMJD2E). ${ }^{22,18}$ Thus, much work has focused on modification of the $\mathbf{3 b}$ scaffold with the intent of generating a cell-active inhibitor that is both potent and selective. Some examples include the 5-position $N$-acylsulfonamide derivatives ${ }^{23}$ and 2-heterocyclic glycinamide derivatives ${ }^{24}$ of $\mathbf{3 b}$ (Figure 2), though these compounds were not developed further due to insufficient activity in cultured cells or intolerable cytotoxicity.

The most potent inhibitor of human CP4Hs identified to date is 2,2'-bipyridine-5,5'dicarboxylic acid (4e, Figure 3). ${ }^{25}$ Whereas the parent compound 2,2'-bipyridine-5-carboxylic acid (5) was found to be a modest inhibitor $\left(\mathrm{IC}_{50}=13 \mu \mathrm{M}\right), 4 \mathrm{e}$ was reported to be substantially more potent $\left(K_{\mathrm{i}}=185 \mathrm{nM}\right){ }^{25}$ The inhibitory mechanism of this compound is, however, not known. 1 itself is well known to inhibit human CP4Hs via iron sequestration rather than enzymic binding. Although structure-activity relationships (SARs) suggest that enzymic binding contributes to inhibition by $\mathbf{4 e},{ }^{25}$ the role of iron sequestration is unclear.

Herein, we investigate 2,2'-bipyridinedicarboxylates as inhibitors of human FAKGDs, both in terms of the relevant inhibitory mechanism(s) and optimum geometry for inhibition. We access a library of seven 2,2'-bipyridinedicarboxylates and assess the ability of each to sequester iron and bind to a $\mathrm{CP} 4 \mathrm{H}$. We find that both $2,2^{\prime}$-bipyridine-4, $5^{\prime}$-dicarboxylate $(\mathbf{4 c})$ and $\mathbf{4 e}$ are nanomolar inhibitors of a $\mathrm{CP} 4 \mathrm{H}$, though both also bind to free $\mathrm{Fe}(\mathrm{II})$. Significantly, we discover that $\mathbf{4 c}$, but not $\mathbf{4 e}$, binds to a human PHD. These data provide a roadmap for developing potent, selective inhibitors of human CP4Hs. 


\section{Results and discussion}

\subsection{2,2'-Bipyridinedicarboxylate library}

We accessed a focused library of 2,2'-bipyridinedicarboxylates (4a-g) (Figure 3). The symmetric members of the library, 2,2'-bipyridine-3,3'-dicarboxylic acid (4a), 2,2'-bipyridine4,4'-dicarboxylic acid (4b), 4e, and 2,2'-bipyridine-6,6'-dicarboxylic acid (4g), were obtained from commercial vendors. The asymmetric members were synthesized by a 4-step route in which the key 2,2'-bipyridine intermediates were accessed by the palladium-catalyzed 2-pyridylation of the corresponding pyridine $N$-oxides (Scheme 1). ${ }^{26-28}$ This route afforded $4 \mathbf{c}, 2,2^{\prime}$-bipyridine-4,6'dicarboxylic acid (4d), and 2,2'-bipyridine-5,6'-dicarboxylic acid (4f) in overall yields of 53\%, $36 \%$, and $15 \%$, respectively.

\subsection{Iron sequestration}

To begin our analysis, we evaluated $\mathbf{4 a}-\mathbf{g}$ as iron chelators. We performed titration experiments to determine the half-maximal concentration required to form a complex with 20 $\mu \mathrm{M} \mathrm{Fe}(\mathrm{II})\left(\mathrm{Fe}_{20}-\mathrm{EC}_{50}\right)$ at $\mathrm{pH} 7.0$, taking advantage of the strong absorption of complexes of $\mathbf{1}$ and related analogues with $\mathrm{Fe}(\mathrm{II})$ (Table 1). Along with an estimation of stoichiometry obtained with Job's method, the $\mathrm{Fe}_{20}-\mathrm{EC}_{50}$ value provides a comparative metric for iron affinity. With the exception of $\mathbf{4 a}$ and $\mathbf{4 g}$, all members of the library were capable of forming distinct red complexes with $\mathrm{Fe}_{20}-\mathrm{EC}_{50}$ values in the micromolar range (see: Supporting Information). Because 1 is already known to inhibit $\mathrm{CP} 4 \mathrm{Hs}$, these results suggest that most of these ligands would inhibit $\mathrm{CP} 4 \mathrm{H} 1$ by sequestering iron under iron-limiting conditions. 


\subsection{CP4H binding}

To identify compounds that inhibit human $\mathrm{CP} 4 \mathrm{H} 1$ through enzymic binding rather than iron sequestration, we next sought to determine the extent to which $\mathbf{1}$ and $\mathbf{4 a}-\mathbf{g}$ form a complex with $\mathrm{Fe}(\mathrm{II})$ under $\mathrm{CP} 4 \mathrm{H}$ assay conditions. Typical in vitro assays for human $\mathrm{CP} 4 \mathrm{Hs}$ employ a tris(hydroxymethyl)aminomethane (Tris) buffer. Although Tris is known to form complexes with metal ions, ${ }^{29,30}$ the use of Tris does not affect the observed hydroxylase activity of purified enzyme. ${ }^{19}$ Still, to determine if $\mathbf{1}$ and $\mathbf{4 a}-\mathbf{g}$ can form iron complexes under our assay conditions, we incubated our $\mathrm{CP} 4 \mathrm{H}$ assay buffer (50 mM Tris- $\mathrm{HCl}$ buffer, $\mathrm{pH} 7.8$, containing $1 \% \mathrm{w} / \mathrm{v}$

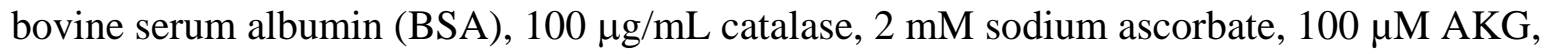
$100 \mu \mathrm{M}$ dithiothreitol (DTT), and $50 \mu \mathrm{M} \mathrm{FeSO}_{4}$ ) at $30{ }^{\circ} \mathrm{C}$ in the presence or absence of $\mathbf{1}$ $(150 \mu \mathrm{M})$, and determined the presence of a $\mathrm{Fe}(\mathbf{1})_{3}{ }^{2+}$ complex using spectrophotometry. Under these conditions, we observed the formation of the $\mathrm{Fe}(\mathbf{1}) 3^{2+}$ complex rapidly and in virtually identical abundance to that observed in unbuffered conditions. Moreover, similar results were observed for complexes with $\mathbf{4 b}, \mathbf{4 c}$, and $\mathbf{4 e}$ ligands. In order of addition experiments, we found that Tris alone inhibits the formation of the $\mathrm{Fe}(\mathbf{1})_{3}{ }^{2+}$, but that the subsequent addition of either sodium ascorbate or DTT allowed for complex formation.

Given these results and the requirement of ascorbate for hydroxylase activity, the design of assay conditions that preclude the formation of $\mathrm{Fe}(\mathrm{II})$ complexes with $\mathbf{1}$ and related analogues is highly unlikely. Thus, we next sought to develop in vitro screening conditions for human CP4Hs such that the inhibitory effect of iron sequestration would be minimal. We chose an initial screening concentration of $10 \mu \mathrm{M}$, which is substantially below the concentration of $\mathrm{FeSO}_{4}$ $(50 \mu \mathrm{M})$ used in the assay. Importantly, 1 showed virtually no inhibition under these screening conditions whereas $\mathbf{3 b}$ showed significant inhibition (Figure 4A), which validates these 
conditions for the discovery of compounds where the primary inhibitory mechanism is other than merely iron sequestration. Although most of the compounds screened under these conditions showed little to no inhibition, both $\mathbf{4 e}$ and $\mathbf{4 c}$ were found to be potent inhibitors (more than $90 \%$ reduction of $\mathrm{CP} 4 \mathrm{H}$ activity) and $\mathbf{4 b}$ was found to be a modest inhibitor that is similar in potency to $\mathbf{3 b}$ (Figure 4A). In subsequent dose-response experiments, the inhibition curves for $\mathbf{4 e}$ and $\mathbf{4 c}$ were found to be sigmoidal (Figure 4B) with $\mathrm{IC}_{50}$ values in the low micromolar range (Table 2). Yet, the inhibition curve for $\mathbf{4 b}$ was found to be non-sigmoidal (see: Supporting Information), which suggests a mixed inhibitory mechanism wherein iron sequestration becomes a contributing factor at higher concentrations (supported by the observation of a red color in the assay solutions). These data suggest that $\mathrm{CP} 4 \mathrm{H} 1$ is inhibited strongly by 2,2'-bipyridinedicarboxylates of two different geometries with almost equal potency, and that the inhibition does not rely upon iron sequestration.

To understand further the potent inhibition observed for $\mathbf{4 e}$ and $\mathbf{4 c}$, we next probed the kinetic mechanism of these compounds. Human CP4Hs have been shown previously to display an ordered ter-ter mechanism in which $\mathrm{AKG}$ first binds to the $\mathrm{CP} 4 \mathrm{H} \cdot \mathrm{Fe}(\mathrm{II})$ complex, after which $\mathrm{O}_{2}$ and the peptide substrate bind in an ordered fashion. ${ }^{19}$ Lineweaver-Burke analyses confirmed that $\mathbf{4 e}$ and $\mathbf{4 c}$ both function as competitive inhibitors with respect to AKG (Figure 5), which suggests that they bind to $\mathrm{CP} 4 \mathrm{H} 1$ in a manner that requires enzymic iron. Based upon the observed competitive inhibition, we used the Cheng-Prussoff equation to estimate values of $K_{\mathrm{i}}$ for these compounds (Table 2). We found that $\mathbf{4 e}$ and $\mathbf{4 c}$ inhibit human CP4H1 with $K_{\mathrm{i}}$ values in the nanomolar range. These $K_{\mathrm{i}}$ values should be taken as upper limits, as it is difficult to take into account the fraction of each that is present in complexes with free iron under assay conditions. Although the competitive inhibition observed here should be interpreted with caution in the 
absence of structural information, these data are consistent with a mechanism in which $\mathbf{4 e}$ and $\mathbf{4 c}$ inhibit human $\mathrm{CP} 4 \mathrm{H} 1$ by binding in the $\mathrm{AKG}$ binding pocket. In addition, we tested the biphenyl analogs of $\mathbf{4 e}$ and $\mathbf{4 c}$ and found that the pyridyl nitrogens were essential for detectable inhibition (data not shown), providing further support for a mechanism in which coordination of the enzymic iron is a requirement.

It is interesting to note the SARs observed above for the 2,2'-bipyridinedicarboxylates parallel that of the pyridinedicarboxylates. For example, human $\mathrm{CP} 4 \mathrm{H} 1$ is inhibited by both 3a and $\mathbf{3 b}$, where the geometry of $\mathbf{3 b}$ is preferred compared to that of $\mathbf{3 a} .{ }^{18}$ Similarly, both $\mathbf{4 e}$ and $\mathbf{4 c}$ (reminiscent of $\mathbf{3 b}$ and $\mathbf{3 a}$, respectively) are accommodated in the active site, where the geometry of $\mathbf{4 e}$ appears to be preferred compared to that of $\mathbf{4 c}$. Yet, it is also important to note that $\mathbf{4 e}$ and $\mathbf{4 c}$ are substantially more potent than the corresponding pyridinedicarboxylates. For example, comparing $\mathbf{3 b}$ and $\mathbf{4 e}$ and assuming energetically similar interactions with the assay buffer, the difference in $K_{\mathrm{i}}$ corresponds to a difference in binding free energy of $\Delta G^{\circ}=(1.7 \pm 0.1) \mathrm{kcal} / \mathrm{mol}$, which is typical for a hydrogen bond. These comparisons suggest that $\mathbf{4 e}$ and $\mathbf{4 c}$ likely bind to human $\mathrm{CP} 4 \mathrm{H} 1$ in a manner similar to the corresponding pyridinedicarboxylates, except that their binding is stabilized further by additional enzymic interactions with the second carboxylate group.

\subsection{Inhibition of PHD2}

We reasoned that the second carboxyl group of $\mathbf{4 e}$ and $\mathbf{4} \mathbf{c}$ could allow for the selective inhibition of CP4Hs over other FAKGDs. This issue is, however, difficult to address in the absence of structural information about the catalytic domain of any human or mammalian $\mathrm{CP} 4 \mathrm{H}$. Although the structure of the N-terminal peptide binding domain of the $\alpha$-subunit has been 
characterized with both X-ray crystallography ${ }^{16,17}$ and NMR spectroscopy, ${ }^{15}$ the structure of the catalytic domain has remained elusive.

Unlike with $\mathrm{CP} 4 \mathrm{H}$, there are numerous crystal structures available for PHD2, including some solved as a complex with AKG or AKG mimics. Moreover, preliminary SARs for PHD2 with respect to simple AKG mimics such as $\mathbf{3 a}, \mathbf{3 b}$, and $\mathbf{2}$ have already been established, facilitating a comparison between the SARs of CP4H1 and PHD2. ${ }^{18}$ For example, 2 and 3a inhibit PHD2 at low micromolar concentrations, but $\mathbf{3 b}$ does not inhibit PHD2 even at high micromolar concentrations. These and other data suggest differences in the active sites of these essential FAKGDs that could be understood further using a combination of both chemical approaches and existing structural information.

Toward this end, we screened our library at $10 \mu \mathrm{M}$ as inhibitors of PHD2. We found that, whereas $\mathbf{4 c}$ (and to a lesser extent $\mathbf{4 b}$ ) inhibited PHD2, most other 2,2'-bipyridinedicarboxylates including 4e showed virtually no inhibition (Figure 6). Moreover, the inhibition observed for 4c was not greater than that observed for simple AKG mimics, such as $\mathbf{2}$ and 3a. These data are consistent with the hypothesis that $\mathbf{4 c}$ is accommodated in the PHD2 active site, but without the engagement of its 5'-carboxyl group in a favorable enzymic interaction. These data are also in agreement with examinations of available crystal structures of PHD2 (PDB entries 3ouj, 3ouh, 2hqu, and $2 \mathrm{~g} 1 \mathrm{~m}$ ), wherein the active site cleft opposite the AKG binding site is exposed to solvent. Using all extant data, we put forth schematic models of 2,2'-bipyridinedicarboxylates with CP4H1 and PHD2 (Figure 7). 


\subsection{Other Isoforms of CP4H}

We note that our investigations have focused on the $\mathrm{CP} 4 \mathrm{H} 1$ holoenzyme rather than the $\mathrm{CP} 4 \mathrm{H} 2$ and $\mathrm{CP} 4 \mathrm{H} 3$ isoforms. This choice was largely due to the relative abundance of $\mathrm{CP} 4 \mathrm{H} 1$ in most tissues compared to that of the other two isoforms. ${ }^{11}$ Nonetheless, BLAST experiments suggest high similarity between the three $\alpha$-subunits, with the $\alpha(\mathrm{I})$-subunit 78 and $56 \%$ similar to the $\alpha(\mathrm{II})-$ and $\alpha(\mathrm{III})$-subunits, respectively. Moreover, these similarities improve to $>85$ and $>63 \%$ when considering only the catalytic domains. Given these high similarities, the SARs identified for $\mathrm{CP} 4 \mathrm{H} 1$ (as well as the model put forth in Figure 7A) could also pertain to $\mathrm{CP} 4 \mathrm{H} 2$ and $\mathrm{CP} 4 \mathrm{H} 3$.

\section{Conclusion}

The need for selective inhibitors of human $\mathrm{CP} 4 \mathrm{Hs}$ with therapeutic potential is evident from the growing list of diseases associated with the overproduction of collagen. The lack of structural information available for mammalian CP4Hs has made the development of such inhibitors difficult, and the understanding of known inhibitors such as compounds $\mathbf{3 b}$ and $\mathbf{4 e}$ likewise evasive. Our investigations of the 2,2'-bipyridinedicarboxylate family reveal new information. For example, $\mathbf{3 b}$ was known to be a selective inhibitor of human $\mathrm{CP} 4 \mathrm{H}$ compared to other FAKGDs, such as the PHDs, FIH, and JMJD2E. ${ }^{18}$ These results, along with additional structureactivity relationships of $\mathbf{3 b}$ analogues, ${ }^{23}$ led researchers to postulate that $\mathbf{3 b}$ could bind to $\mathrm{CP} 4 \mathrm{H}$ in a manner that is distinct from the conventional AKG binding mode, possibly taking advantage of alternative coordination sites on the enzymic iron center. Our finding that $\mathbf{4 c}$ and $\mathbf{4 e}$ are competitive inhibitors of human $\mathrm{CP} 4 \mathrm{H} 1$ with almost equal potency contrasts with the previous postulate and suggests that the AKG-binding pocket of this enzyme is likely able to 
accommodate two different inhibitor geometries (reminiscent of the geometries of either 3a or 3b) in the conventional AKG binding mode. Still, the exact structural and/or conformational features that allow for this accommodation are not yet understood.

Although achieving selectivity for CP4Hs over other FAKGDs is ideal, it is especially important to achieve selectivity over PHD2. For example, in hypoxic breast cancers, the expression of the $\mathrm{CP} 4 \mathrm{H} \alpha(\mathrm{I})$-and $\alpha(\mathrm{II})$-subunits is upregulated in a PHD2-dependent manner, which ultimately contributes to the metastatic potential of these tumors. ${ }^{7}$ More specifically, the loss in PHD2 activity due to hypoxia allows the accumulation of the PHD2 substrate and transcription factor HIF-1 $\alpha$, which ultimately enhances the expression of these metastatically important $\mathrm{CP} 4 \mathrm{H} \alpha$-subunits. ${ }^{7}$ Although treatment with a $\mathrm{CP} 4 \mathrm{H}$ inhibitor could be a viable strategy to disrupt breast cancer metastasis, that inhibitor must avoid inhibition of PHD2 so as to prevent a consequent increase in the target CP4Hs. Indeed, the poor performance of many previously characterized $\mathrm{CP} 4 \mathrm{H}$ inhibitors in cells could be due, at least in part, to the off-target effects associated with inhibiting PHD2. Our finding that both $\mathbf{4} \mathbf{c}$ and $\mathbf{4 e}$ are substantially more potent towards human $\mathrm{CP} 4 \mathrm{H} 1$ compared to simple AKG mimics, as well as the finding that this increased potency does not occur when inhibiting PHD2, suggests the existence of additional $\mathrm{CP} 4 \mathrm{H} 1$ residues that can be used to achieve the desired selectivity. Although the identity of these residues is unclear, previous investigations of the $\mathbf{4 e}$ scaffold showed that additional functional groups such as anilides and sulfonamides are tolerated as replacements of the $5^{\prime}$-carboxylate, ${ }^{23,25}$ suggesting that the interaction(s) in this second site might not necessarily be Coulombic in nature.

Lastly, we note that our data reveal that both compound $\mathbf{4 c}$ and compound $\mathbf{4 e}$ are potent inhibitors of $\mathrm{CP} 4 \mathrm{H} 1$ and that inhibition arises largely through enzymic binding. Still, $\mathbf{4 c}$ and $\mathbf{4 e}$ 
do bind to free Fe(II), which could compromise therapeutic efficacy. Our future work will seek to modify these scaffolds to limit Fe(II) binding while maintaining selective affinity for CP4Hs.

\section{Experimental section}

\subsection{General experimental procedures}

Compounds 1, 3a, 3b, 4a, and 4e were from Sigma-Aldrich (St. Louis, MO). Compound 4b was from TCI America (Portland, OR). Compound 4g was from CMS Chemicals (Compton, UK). Biphenyl-4,4'-dicarboxylic acid was from Acros Organics (Geel, Belgium), and biphenyl3,4'-dicarboxylic acid was from Combi-Blocks (San Diego, CA). Phosphine ligands and phosphonium salts were from either Sigma-Aldrich or Strem (Newberryport, MA), stored in a dessicator, and used without further purification. $\mathrm{Pd}(\mathrm{OAc})_{2}$ was from Sigma-Aldrich, stored in a dessicator, and used without further purification. HIF-1 $\alpha$ peptide ${ }_{556-574}$ was from AnaSpec (Fremont, CA) and used without further purification. All other reagent chemicals were from Sigma-Aldrich, Acros Organics, Combi-Blocks, Oakwood Products (West Columbia, SC), Enamine (Monmouth Junction, NJ), Bachem (Bubendorf, Switzerland), or CalbiochemNovabiochem (San Diego, CA), and were used without further purification.

All glassware was flame- or oven-dried, and reactions were performed under $\mathrm{N}_{2}(\mathrm{~g})$ unless indicated otherwise. Dichloromethane and toluene were dried over a column of alumina. Dimethylformamide was dried over alumina and further purified through an isocyanate scrubbing column. Other anhydrous solvents were obtained in septum-sealed bottles. Flash chromatography was performed with columns of 40-63 A silica gel, 230-400 mesh from Silicycle (Québec City, Canada). Thin-layer chromatography (TLC) was performed on plates $250-\mu \mathrm{m}$ silica $60-\mathrm{F}_{254}$ from EMD Merck (Darmstadt, Germany) with visualization by UV light 
irradiation or staining with $\mathrm{KMnO}_{4}$. The phrase "concentrated under reduced pressure" refers to the removal of solvents and other volatile materials using a rotary evaporator at water aspirator pressure ( $<20$ torr) while maintaining water-bath temperature below $40{ }^{\circ} \mathrm{C}$. Residual solvent was removed from samples at high vacuum ( $<0.1$ torr). The term "high vacuum" refers to vacuum achieved by a mechanical belt-drive oil pump. All reported yields are unoptimized. The purity of all synthesized compounds was assessed by HPLC, and the purity of all final compounds was found to be greater than $95 \%$.

\subsection{Instrumentation}

Melting points were determined with a PMA160 digital melting apparatus from Stanford Research Systems (Sunnyvale, CA). NMR spectra were acquired at ambient temperature with a DMX-400 Avance spectrometer or a Avance 500i spectrometer from Bruker (Billerica, MA) at the National Magnetic Resonance Facility at Madison (NMRFAM) and were referenced to TMS or a residual protic solvent. Some compounds exist as either mixtures of rotamers or tautomers that do not interconvert on the NMR timescale at ambient temperature and therefore exhibit multiple sets of NMR signals (as indicated). Electrospray ionization (ESI) and electron ionization (EI) mass spectrometry were performed with a Micromass $\mathrm{LCT}^{\circledR}$ and Micromass AutoSpec $^{\circledR}$ instruments, respectively, from Waters (Milford, MA) at the Mass Spectrometry Facility in the Department of Chemistry at the University of Wisconsin-Madison. The progress of reactions catalyzed by prolyl 4-hydroxylases was determined by analytical HPLC using a system from Waters equipped with a 996 photodiode array detector and Empower 2 software. Compound purity was also determined using the Waters HPLC system above. Preparative HPLC was performed using a Prominence HPLC instrument from Shimadzu (Kyoto, Japan) equipped 
with two LC-20AP pumps, SPD-M20A photodiode array detector, and CTO-20A column oven. Iron complexes with bipyridine ligands were analyzed by spectrophotometry using a Cary 60 UV-Vis spectrometer from Agilent Technologies (Santa Clara, CA). Protein concentrations were calculated from their absorbance at $280 \mathrm{~nm}$ as measured with a NanoVue Plus spectrophotometer from GE Healthcare using an extinction coefficient of $290,000 \mathrm{M}^{-1} \mathrm{~cm}^{-1}$ for human $\mathrm{CP} 4 \mathrm{H}^{31}$ and $36,900 \mathrm{M}^{-1} \mathrm{~cm}^{-1}$ for human PHD2. ${ }^{32} \mathrm{IC}_{50}$ - and $\mathrm{EC}_{50}$-values were calculated from experimental data with Prism version 6.0 software from GraphPad Software (La Jolla, CA).

\subsection{Production of recombinant human CP4H1}

Human $\mathrm{CP} 4 \mathrm{H}$ containing the $\alpha(\mathrm{I})$ isoform was produced heterologously in Origami $\mathrm{B}(\mathrm{DE} 3)$ Escherichia coli cells and purified as described previously. ${ }^{31}$

\subsection{Assay of human CP4H1 activity in the presence of inhibitors}

The catalytic activity of human CP4H1 was assayed as described previously. ${ }^{31}$ Briefly, activity assays were carried out at $30{ }^{\circ} \mathrm{C}$ in $100 \mu \mathrm{L}$ of Tris- $\mathrm{HCl}$ buffer, $\mathrm{pH} 7.8$, containing human CP4H1 (100 nM), inhibitor (0-500 $\mu \mathrm{M})$, substrate (dansylGlyProProGlyOEt, $500 \mu \mathrm{M})$, $\mathrm{FeSO}_{4}(50 \mu \mathrm{M})$, BSA $(1 \mathrm{mg} / \mathrm{mL})$, catalase $(0.1 \mathrm{mg} / \mathrm{mL})$, ascorbate $(2 \mathrm{mM})$, DTT $(100 \mu \mathrm{M})$, and $\alpha$-ketoglutarate $(100 \mu \mathrm{M})$. Reaction mixtures were pre-incubated with or without inhibitor for 2 min at $30{ }^{\circ} \mathrm{C}$, after which the reaction was initiated by the addition of $\alpha$-ketoglutarate. After $15 \mathrm{~min}$, reactions were quenched by boiling for $45 \mathrm{~s}$ and centrifuged at $10,000 \mathrm{~g}$. The supernatant $(20-50 \mu \mathrm{L})$ was injected into a Nucleodur ${ }^{\circledR} \mathrm{C} 18$ Gravity reversed-phase column $(4.6 \times 250 \mathrm{~mm}$, 5- $\mu \mathrm{m}$ particle size) from Macherey-Nagel (Bethlehem, PA). The column was eluted at $1 \mathrm{~mL} / \mathrm{min}$ with a gradient of aqueous acetonitrile (20-45\% over $20 \mathrm{~min}$ ) containing $0.1 \% \mathrm{v} / \mathrm{v}$ TFA. The 
absorbance of the eluent was monitored at $289 \mathrm{~nm}$. All assays were performed in triplicate. Data is reported as activity relative to control reactions lacking inhibitor, where activity is determined from the percent conversion of substrate to product. Dose-response curves were generated for each inhibitor by plotting the relative activity versus the $\log$ of the inhibitor concentration. $\mathrm{IC}_{50^{-}}$ values for each inhibitor were interpolated from the dose-response curves by non-linear regression using the sigmoidal dose-response function within the Prism software.

\subsection{Production of human PHD2}

A cDNA encoding human PHD2 $2_{181-426}$ possessing an N-terminal hexahistidine $\left(\mathrm{His}_{6}\right)$ tag (NHis $_{6}$-PHD2 ${ }_{181-426}$ ) was cloned using the Gibson strategy, ${ }^{33}$ and the encoded protein was produced and purified as described previously. ${ }^{32}$

\subsection{Assay of human PHD2 activity in the presence of inhibitors}

The catalytic activity of human PHD2 in the absence or presence of putative inhibitors was assayed as described previously. ${ }^{32}$ Briefly, activity assays were carried out at $30{ }^{\circ} \mathrm{C}$ in $100 \mu \mathrm{L}$ of Tris-HCl buffer, $\mathrm{pH} 7.8$, containing human $\mathrm{NHis}_{6}-\mathrm{PHD}_{181-426}(5 \mu \mathrm{M})$, inhibitor $(0-10 \mu \mathrm{M})$, substrate $\left(\mathrm{HIF}-1 \alpha\right.$ peptide $\left._{556-574}, 50 \mu \mathrm{M}\right), \mathrm{FeSO}_{4}(50 \mu \mathrm{M}), \mathrm{BSA}(1 \mathrm{mg} / \mathrm{mL})$, catalase $(0.3$ $\mathrm{mg} / \mathrm{mL})$, ascorbate $(2 \mathrm{mM})$, DTT $(1 \mathrm{mM})$, and $\alpha$-ketoglutarate $(35 \mu \mathrm{M})$. Reactions were preincubated with or without inhibitor for $2 \mathrm{~min}$ at $30{ }^{\circ} \mathrm{C}$, after which the reaction was initiated by the addition of $\alpha$-ketoglutarate. After $10 \mathrm{~min}$, reactions were quenched by boiling for $60 \mathrm{~s}$ and centrifugation at $10,000 \mathrm{~g}$. The supernatant $(50 \mu \mathrm{L})$ was injected into a Nucleodur ${ }^{\circledR} \mathrm{C} 18$ Gravity reversed-phase column $(4.6 \times 250 \mathrm{~mm}, 5 \mu \mathrm{m}$ particle size $)$ from Macherey-Nagel. The column was eluted at $1 \mathrm{~mL} / \mathrm{min}$ with a gradient of aqueous acetonitrile (5-56\% over $34 \mathrm{~min}$ ) containing 
$0.1 \% \mathrm{v} / \mathrm{v}$ TFA. The absorbance of the eluent was monitored at $218 \mathrm{~nm}$. All assays were performed in triplicate. Data is reported as activity relative to control reactions lacking inhibitor, where activity is determined from the percent conversion of substrate to product.

\subsection{Assay of Fe(II)-affinity of bipyridine compounds}

The affinity of bipyridine compounds for Fe(II) was determined comparatively by measuring the half maximal concentration $\left(\mathrm{EC}_{50}\right)$ required for binding $20 \mu \mathrm{M} \mathrm{Fe}(\mathrm{II})\left(\mathrm{Fe}_{20}-\mathrm{EC}_{50}\right)$ in sodium phosphate buffer, pH 7.0. Stock solutions of ligands were prepared in water. Stock solutions of $\mathrm{FeSO}_{4}$ were prepared in $\mathrm{H}_{2} \mathrm{O}$ and used within $3 \mathrm{~h}$ of preparation. Ligand solutions $(3-500 \mu \mathrm{M}$ depending on affinity) were prepared in $10 \mathrm{mM}$ sodium phosphate buffer, $\mathrm{pH}$ 7.0, after which $\mathrm{Fe}(\mathrm{II})$ stock solution was added to initiate complex formation. Solutions were allowed to equilibrate for $15 \mathrm{~min}$, after which the absorbance was recorded at the $\lambda_{\max }$ for the complex under study. Absorbance values were corrected by subtracting the absorbance value in the absence of ligand. Dose-response curves were generated for each ligand by plotting the absorbance versus the log of the ligand concentration. $\mathrm{Fe}_{20}-\mathrm{EC}_{50}$ values for each ligand were interpolated from the dose-response curves by non-linear regression using the sigmoidal doseresponse function in Prism. All experiments were performed in triplicate.

\subsection{Determination of $\mathrm{Fe}(\mathrm{II})$ complex stoichiometry}

The stoichiometry of complexes formed by bipyridine ligands and $\mathrm{Fe}(\mathrm{II})$ was estimated with Job's method. ${ }^{34,35}$ Briefly, solutions were prepared such that the concentration of ligand and $\mathrm{Fe}(\mathrm{II})$ were kept at $0.4 \mathrm{mM}$, but the mole fraction of the ligand was varied from 0 to 1 . Stock solutions of ligands were prepared in water. Stock solutions of $\mathrm{FeSO}_{4}$ were prepared in water and 
used within $3 \mathrm{~h}$ of preparation. Mixtures were prepared in $10 \mathrm{mM}$ sodium phosphate buffer, $\mathrm{pH}$ 7.0, and complex formation was initiated by the addition of the Fe(II) solution. Solutions were allowed to equilibrate for $15 \mathrm{~min}$, after which the absorbance was recorded at the appropriate $\lambda_{\max }$ for the complex under study. Absorbance values were corrected by subtracting the absorbance value of a blank solution in the absence of $\mathrm{FeSO}_{4}$, after which the values were normalized relative to the mixture with the highest absorbance value. All experiments were performed at least in duplicate. Job plots were constructed by plotting the normalized absorbance versus the mole fraction of bipyridine ligand, after which the stoichiometry of the complex was estimated from the value on the abscissa of the point of intersection for the two best-fit lines approaching the point of maximum absorbance.

\subsection{Determination of compound purity}

All synthesized compounds were analyzed by HPLC to determine their purity. The analyses were performed on the Waters HPLC system using a Nucleodur ${ }^{\circledR} \mathrm{C} 18$ Gravity reversed-phase column $(4.6 \times 250 \mathrm{~mm}, 5-\mu \mathrm{m}$ particle size $)$ from Macherey-Nagel. Samples $(50 \mu \mathrm{L})$ dissolved in $\mathrm{H}_{2} \mathrm{O}$ were injected into the column and eluted at $1 \mathrm{~mL} / \mathrm{min}$ with a gradient of aqueous acetonitrile (5-95\% v/v over $20 \mathrm{~min}$ ) containing $0.1 \% \mathrm{v} / \mathrm{v}$ TFA. The maximal absorbance in the range of $210-400 \mathrm{~nm}$ was used as the detection wavelength.

\subsection{Synthesis}

\subsubsection{3-Methoxycarbonylpyridine $N$-oxide}

Methyl nicotinate (2.0 g, 14.6 mmoles) and $m$-chloroperoxybenzoic acid (6.5 g, 29.2 mmoles) were dissolved in dry dichloromethane $(150 \mathrm{~mL})$ in a flame-dried flask. This reaction 
mixture was stirred at room temperature for $24 \mathrm{~h}$. The solution was concentrated under reduced pressure, and the resulting residue was purified by chromatography on silica (5-20\% $\mathrm{MeOH}$ in acetone) to afford the title compound as a pale yellow solid $(2.19 \mathrm{~g}, 98 \%)$ with $\mathrm{mp} 94.6-99.1{ }^{\circ} \mathrm{C}$. ${ }^{1}$ H NMR (400 MHz, $\left.\mathbf{C D C l}_{3}, \delta\right): 8.77(\mathrm{~s}, 1 \mathrm{H}), 8.34(\mathrm{~d}, J=6.8 \mathrm{~Hz}, 1 \mathrm{H}), 7.86(\mathrm{~d}, J=8.0 \mathrm{~Hz}, 1$ H), $7.38(\mathrm{dd}, J=6.8,8.0 \mathrm{~Hz}, 1 \mathrm{H}), 3.98(\mathrm{~s}, 3 \mathrm{H}) ;{ }^{\mathbf{1 3}} \mathbf{C}$ NMR (100 MHz, $\left.\mathbf{C D C l}_{3}, \delta\right):$ 163.2, 142.5, 140.3, 129.9, 126.2, 125.8, 53.1; HRMS (ESI) $m / z$ 154.0494 [calc'd for $\mathrm{C}_{7} \mathrm{H}_{8} \mathrm{NO}_{3}(\mathrm{M}+\mathrm{H})^{+}$ 154.0499].

\subsubsection{4-Methoxycarbonylpyridine $N$-Oxide}

Methyl isonicotinate $(1.8 \mathrm{~mL}, 15.2 \mathrm{mmoles})$ and $m$-chloroperoxybenzoic acid ( $6.8 \mathrm{~g}, 30.4$ mmoles) were dissolved in dry dichloromethane $(150 \mathrm{~mL})$ in a flame-dried flask. This reaction mixture was stirred at room temperature for $24 \mathrm{~h}$. The solution was concentrated under reduced pressure, and the resulting residue was purified by chromatography on silica $(1-4 \% \mathrm{v} / \mathrm{v} \mathrm{MeOH}$ in acetone) to afford the title compound as a white solid $(2.26 \mathrm{~g}, 97 \%)$ with $\mathrm{mp} 118.1-121.3{ }^{\circ} \mathrm{C}$.

${ }^{1}$ H NMR (400 MHz, $\left.\mathbf{C D C l}_{3}, \boldsymbol{\delta}\right): 8.20(\mathrm{~d}, J=4.0 \mathrm{~Hz}, 2 \mathrm{H}), 7.84(\mathrm{~d}, J=4.0 \mathrm{~Hz}, 2 \mathrm{H}), 3.90$ (s, 3 H); ${ }^{13}$ C NMR (100 MHz, $\left.\mathbf{C D C l}_{3}, \boldsymbol{\delta}\right):$ 163.7, 139.4, 126.5, 126.4, 52.8; HRMS (ESI) $\mathrm{m} / \mathrm{z}$ 154.0492 [calc'd for $\mathrm{C}_{7} \mathrm{H}_{8} \mathrm{NO}_{3}(\mathrm{M}+\mathrm{H})^{+} 154.0499$ ].

\subsubsection{5-Methoxycarbonyl-2-(4-methoxycarbonylpyridin-2-yl)pyridine $N$-oxide}

$\mathrm{Pd}(\mathrm{OAc})_{2}(36 \mathrm{mg}, 0.16$ mmoles $),\left[\mathrm{P}(t-\mathrm{Bu})_{3} \mathrm{H}\right] \mathrm{BF}_{4}$ (142 mg, 0.49 mmoles), $\mathrm{K}_{2} \mathrm{CO}_{3}(903 \mathrm{mg}$, 6.5 mmoles), methyl 2-bromoisonicotinate (705 mg, $3.3 \mathrm{mmoles})$, and 3-methoxycarbonylpyridine $\mathrm{N}$-oxide (2000 mg, 13 mmoles) were added to a dried flask. The flask was fitted with a reflux condenser capped with a septum, evacuated, and purged with $\mathrm{N}_{2}(\mathrm{~g})$ 
( $\sim 5$ times). Dry toluene $(22 \mathrm{~mL})$ was added via syringe, and the reaction mixture was stirred at $110{ }^{\circ} \mathrm{C}$ for $18 \mathrm{~h}$. The reaction mixture was cooled to room temperature and filtered through Celite $^{\circledR}$, and the filtrate was concentrated under reduced pressure. The crude product was then purified by chromatography on silica (15\% acetone in 1:1 DCM/hexanes) to afford the title compound (537 mg, 57\%) as a pale orange solid with mp 170.6-174.1 ${ }^{\circ} \mathrm{C} .{ }^{\mathbf{1}} \mathbf{H}$ NMR (400 MHz, $\left.\mathbf{C D C l}_{3}, \delta\right): 9.49(\mathrm{~s}, 1 \mathrm{H}), 8.89(\mathrm{~s}, 1 \mathrm{H}), 8.88(\mathrm{~d}, J=5.2 \mathrm{~Hz}, 1 \mathrm{H}), 8.30(\mathrm{~d}, J=8.4 \mathrm{~Hz}, 1 \mathrm{H}), 7.94$ $(\mathrm{dd}, J=1.2,5.2 \mathrm{~Hz}, 1 \mathrm{H}), 7.90(\mathrm{dd}, J=1.2,8.4 \mathrm{~Hz}, 1 \mathrm{H}), 3.98(\mathrm{~s}, 3 \mathrm{H}), 3.97(\mathrm{~s}, 3 \mathrm{H}) ;{ }^{\mathbf{1 3}} \mathbf{C}$ NMR (100 MHz, $\mathbf{C D C l}_{3}$, d): 165.3, 163.4, 150.2, 149.9, 149.4, 141.9, 138.0, 128.9, 127.7, 125.7, 124.9, 124.1, 53.1, 52.8; HRMS (ESI) $m / z$ 289.0826 [calc'd for $\mathrm{C}_{14} \mathrm{H}_{13} \mathrm{~N}_{2} \mathrm{O}_{5}(\mathrm{M}+\mathrm{H})^{+}$289.0819].

\subsubsection{4-Methoxycarbonyl-2-(6-methoxycarbonylpyridin-2-yl)pyridine $N$-oxide}

$\mathrm{Pd}(\mathrm{OAc})_{2}$ (15.6 mg, 0.070 mmoles), $\left[\mathrm{P}(t-\mathrm{Bu}){ }_{3} \mathrm{H}\right] \mathrm{BF}_{4}$ (60.4 mg, $\left.0.21 \mathrm{mmoles}\right), \mathrm{K}_{2} \mathrm{CO}_{3}(384$ mg, 2.8 mmoles), methyl 2-bromopicolinate (300 mg, 1.4 mmoles), and 4methoxycarbonylpyridine $N$-oxide ( $858 \mathrm{mg}, 5.6$ mmoles) were added to a dried flask. The flask was fitted with a reflux condenser capped with a septum, evacuated, and purged with $\mathrm{N}_{2}(\mathrm{~g})$ ( $\sim$ times). Dry toluene $(9.0 \mathrm{~mL})$ was added via syringe, and the reaction mixture was stirred at $110^{\circ} \mathrm{C}$ for $24 \mathrm{~h}$. The reaction mixture was cooled to room temperature and filtered through Celite $^{\circledR}$, and the filtrate was concentrated under reduced pressure. The crude product was purified by chromatography on silica ( $1 \% \mathrm{v} / \mathrm{v} \mathrm{MeOH}$ in EtOAc) to afford the title compound (266 mg, $66 \%)$ as a pale yellow solid with mp 193.3-197.0 ${ }^{\circ} \mathrm{C} .{ }^{\mathbf{1}} \mathbf{H}$ NMR (400 $\left.\mathbf{M H z}, \mathbf{C D C l}_{3}, \delta\right): 8.88(\mathrm{~d}, J$ $=8.0 \mathrm{~Hz}, 1 \mathrm{H}), 8.74(\mathrm{~d}, J=2.4 \mathrm{~Hz}, 1 \mathrm{H}), 8.31(\mathrm{~d}, J=6.8 \mathrm{~Hz}, 1 \mathrm{H}), 8.18,(\mathrm{~d}, J=7.6 \mathrm{~Hz}, 1 \mathrm{H})$, $7.99(\mathrm{t}, J=7.6 \mathrm{~Hz}, 1 \mathrm{H}), 7.87(\mathrm{dd}, J=2.4,6.8 \mathrm{~Hz}, 1 \mathrm{H}) ;{ }^{13} \mathbf{C} \mathbf{N M R}\left(\mathbf{1 0 0} \mathbf{M H z}, \mathbf{C D C l}_{3}, \delta\right): 165.3$, $163.4,150.2,149.9,149.4,141.9,138.0,128.9,127.7,125.7,124.9,124.1,53.1,52.8 ;$ HRMS 
(ESI) $m / z$ 289.0818 [calc'd for $\left.\mathrm{C}_{14} \mathrm{H}_{13} \mathrm{~N}_{2} \mathrm{O}_{5}(\mathrm{M}+\mathrm{H})^{+} 289.0819\right]$.

\subsubsection{5-Methoxycarbonyl-2-(4-methoxycarbonylpyridin-2-yl)pyridine $N$-oxide}

$\mathrm{Pd}(\mathrm{OAc})_{2}(10.1 \mathrm{mg}, 0.045$ mmoles $),\left[\mathrm{P}(t-\mathrm{Bu})_{3} \mathrm{H}\right] \mathrm{BF}_{4}(39.2 \mathrm{mg}, 0.14$ mmoles $), \mathrm{K}_{2} \mathrm{CO}_{3}$

(248 mg, 1.8 mmoles), methyl 2-bromopicolinate (195 mg, 0.9 mmoles), and

3-methoxycarbonylpyridine $N$-oxide (553 mg, 3.6 mmoles) were added to a dried flask. The

flask was fitted with a reflux condenser capped with a septum, evacuated, and purged with $\mathrm{N}_{2}(\mathrm{~g})$ ( $~ 5$ times). Dry toluene $(6.0 \mathrm{~mL})$ was added via syringe, and the reaction mixture was stirred at $110{ }^{\circ} \mathrm{C}$ for $24 \mathrm{~h}$. The reaction mixture was cooled to room temperature and filtered through Celite $^{\circledR}$, and the filtrate was concentrated under reduced pressure. The crude product was then purified by chromatography on silica (EtOAc) to afford the title compound (135 $\mathrm{mg}, 52 \%)$ as a pale orange solid with mp 159.7-162.0 ${ }^{\circ} \mathrm{C} .{ }^{\mathbf{1}} \mathbf{H} \mathbf{N M R}\left(\mathbf{4 0 0} \mathbf{~ M H z}, \mathbf{C D C l}_{\mathbf{3}}, \boldsymbol{\delta}\right): 9.10(\mathrm{~d}, J=8.0 \mathrm{~Hz}$, $1 \mathrm{H}), 8.82(\mathrm{~d}, J=0.8 \mathrm{~Hz}, 1 \mathrm{H}), 8.34(\mathrm{~d}, J=8.4 \mathrm{~Hz}, 1 \mathrm{H}), 8.13(\mathrm{~d}, J=7.6 \mathrm{~Hz}, 1 \mathrm{H}), 7.96(\mathrm{t}, J=$ $8.0 \mathrm{~Hz}, 1 \mathrm{H}), 7.86(\mathrm{dd}, J=1.2,8.4 \mathrm{~Hz}, 1 \mathrm{H}), 3.97(\mathrm{~s}, 3 \mathrm{H}), 3.93$ (s, $3 \mathrm{H}) ;{ }^{13} \mathbf{C}$ NMR (100 MHz, $\mathbf{C D C l}_{3}, \delta$ ): $165.1,163.3,149.2,149.0,147.8,141.7,137.5,128.9,128.6,128.0,125.9,125.9$, 53.0, 52.9; HRMS (ESI) $m / z$ 289.0815 [calc'd for $\mathrm{C}_{14} \mathrm{H}_{13} \mathrm{~N}_{2} \mathrm{O}_{5}(\mathrm{M}+\mathrm{H})^{+}$289.0819].

\subsubsection{Dimethyl 2,2'-bipyridine-4,5'-dicarboxylate}

4-Methoxycarbonyl-2-(5-methoxycarbonylpyridin-2-yl)pyridine $\mathrm{N}$-oxide (75 mg, 0.26 mmoles $)$ was dissolved in dry $\mathrm{CHCl}_{3}(8.7 \mathrm{~mL})$, and $\mathrm{PCl}_{3}(30 \mu \mathrm{L}, 0.31$ mmoles $)$ was added to the resulting solution. The ensuing reaction mixture was stirred at $60{ }^{\circ} \mathrm{C}$ until the starting material was consumed completely, as judged by TLC $(6 \mathrm{~h})$. The reaction mixture was quenched by the dropwise addition of saturated aqueous $\mathrm{Na}_{2} \mathrm{CO}_{3}(10 \mathrm{~mL})$ while stirring on ice. The 
product was extracted with $\mathrm{CHCl}_{3}(4 \times 10 \mathrm{~mL})$, and the combined organics were dried over $\mathrm{Na}_{2} \mathrm{SO}_{4}(\mathrm{~s})$ and concentrated under reduced pressure to afford the title compound (69 $\left.\mathrm{mg}, 98 \%\right)$ as a pale yellow solid with mp 163.1-165.2 ${ }^{\circ} \mathrm{C}$. ${ }^{\mathbf{1}} \mathbf{H}$ NMR (400 $\left.\mathbf{~ M H z , ~} \mathbf{C D C l}_{3}, \boldsymbol{\delta}\right): 9.30(\mathrm{~d}, J=1.6$ $\mathrm{Hz}, 1 \mathrm{H}), 9.00(\mathrm{~s}, 1 \mathrm{H}), 8.85(\mathrm{~d}, J=5.2 \mathrm{~Hz}, 1 \mathrm{H}), 8.52$ (d, $J=8.0 \mathrm{~Hz}, 1 \mathrm{H}), 8.43$ (dd, $J=2.0,8.4$ Hz, $1 \mathrm{H}), 7.92(\mathrm{dd}, J=1.6,5.2 \mathrm{~Hz}, 1 \mathrm{H}), 4.01$ (s, $3 \mathrm{H}), 3.99(\mathrm{~s}, 1 \mathrm{H}) ;{ }^{13} \mathbf{C}$ NMR (100 MHz, $\left.\mathbf{C D C l}_{3}, \boldsymbol{\delta}\right): 165.7,165.5,158.6,156.2,150.6,150.1,138.6,138.1,126.0,123.5,121.1,120.6$ 52.8, 52.5; HRMS (ESI) $m / z 273.0882$ [calc'd for $\mathrm{C}_{14} \mathrm{H}_{13} \mathrm{~N}_{2} \mathrm{O}_{4}(\mathrm{M}+\mathrm{H})^{+}$273.0870].

\subsubsection{Dimethyl 2,2'-bipyridine-4,6'-dicarboxylate}

4-Methoxycarbonyl-2-(6-methoxycarbonylpyridin-2-yl)pyridine $\mathrm{N}$-oxide (200 mg, 0.69 mmoles) was dissolved in dry $\mathrm{CHCl}_{3}(23 \mathrm{~mL}) . \mathrm{PCl}_{3}(76 \mu \mathrm{L}, 0.83$ mmoles $)$ was added to the resulting solution. The ensuing reaction mixture was stirred at $60{ }^{\circ} \mathrm{C}$ until the starting material was consumed completely, as judged by TLC. The reaction mixture was quenched by the dropwise addition of saturated aqueous $\mathrm{Na}_{2} \mathrm{CO}_{3}(25 \mathrm{~mL})$ while stirring on ice. The product was extracted with $\mathrm{CHCl}_{3}(4 \times 25 \mathrm{~mL})$, and the combined organics were dried over $\mathrm{Na}_{2} \mathrm{SO}_{4}(\mathrm{~s})$ and concentrated under reduced pressure to afford the title compound (145 $\mathrm{mg}, 77 \%)$ as a pale yellow solid with mp 182.5-185.0 ${ }^{\circ} \mathrm{C} .{ }^{\mathbf{1}} \mathbf{H}$ NMR (400 $\mathbf{M H z}, \mathbf{C D C l}_{3}, \delta$ ): 9.03 (s, $\left.1 \mathrm{H}\right), 8.86$ (d, $J$ $=5.2 \mathrm{~Hz}, 1 \mathrm{H}), 8.63(\mathrm{~d}, J=7.6 \mathrm{~Hz}, 1 \mathrm{H}), 8.18(\mathrm{~d}, J=7.6 \mathrm{~Hz}, 1 \mathrm{H}), 8.01(\mathrm{t}, J=8.0 \mathrm{~Hz}, 1 \mathrm{H}), 7.91$

$(\mathrm{d}, J=8.0 \mathrm{~Hz}, 1 \mathrm{H}), 4.05(\mathrm{~s}, 3 \mathrm{H}), 4.01(\mathrm{~s}, 3 \mathrm{H}) ;{ }^{13} \mathbf{C} \mathbf{N M R}\left(\mathbf{1 0 0} \mathbf{M H z}, \mathbf{C D C l}_{\mathbf{3}}, \boldsymbol{\delta}\right):$ 165.6, 165.3, 155.9, 149.3, 147.9, 139.4, 138.2, 125.6, 124.7, 123.6, 121.3, 52.9, 52.9; HRMS (ESI) $\mathrm{m} / \mathrm{z}$ 273.0863 [calc'd for $\mathrm{C}_{14} \mathrm{H}_{13} \mathrm{~N}_{2} \mathrm{O}_{4}(\mathrm{M}+\mathrm{H})^{+} 273.0870$ ].

\subsubsection{Dimethyl 2,2'-bipyridine-5,6'-dicarboxylate}


5-Methoxycarbonyl-2-(6-methoxycarbonylpyridin-2-yl)pyridine $\mathrm{N}$-oxide (127 mg, 0.44 mmoles) was dissolved in dry $\mathrm{CHCl}_{3}(14.7 \mathrm{~mL})$, after which $\mathrm{PCl}_{3}(50 \mu \mathrm{L}, 0.53$ mmoles $)$ was added. The reaction mixture was stirred at $60{ }^{\circ} \mathrm{C}$ until the starting material was consumed completely, as judged by TLC. The reaction was quenched by the dropwise addition of saturated aqueous $\mathrm{Na}_{2} \mathrm{CO}_{3}(15 \mathrm{~mL})$ while stirring on ice. The product was extracted with $\mathrm{CHCl}_{3}(5 \times$ $15 \mathrm{~mL}$ ), and the combined organics were dried over $\mathrm{Na}_{2} \mathrm{SO}_{4}(\mathrm{~s})$ and concentrated under reduced pressure to afford the title compound $(61 \mathrm{mg}, 53 \%)$ as a pale yellow solid with $\mathrm{mp} 170.9$ $172.3{ }^{\circ} \mathrm{C} .{ }^{1} \mathbf{H}$ NMR $\left(400 \mathbf{M H z} \mathbf{C D C l}_{3}, \delta\right): 9.25(\mathrm{~d}, J=2.0 \mathrm{~Hz}, 1 \mathrm{H}), 8.66(\mathrm{~d}, J=7.6 \mathrm{~Hz}, 1 \mathrm{H})$, $8.62(\mathrm{~d}, J=7.6 \mathrm{~Hz}, 1 \mathrm{H}), 8.41(\mathrm{dd}, J=2.0,8.4 \mathrm{~Hz}, 1 \mathrm{H}), 8.16(\mathrm{~d}, J=8.0 \mathrm{~Hz}, 1 \mathrm{H}), 7.98(\mathrm{t}, J=$ 8.0 Hz, $1 \mathrm{H}), 4.03$ (s, $3 \mathrm{H}), 3.97$ (s, $3 \mathrm{H}) ;{ }^{13} \mathbf{C}$ NMR (100 MHz, $\mathbf{C D C l}_{3}, \delta$ ): 165.6, 165.6, 158.4, 155.2, 150.4, 147.7, 138.1, 138.1, 126.1, 125.7, 125.0, 121.1, 52.9, 52.4; HRMS (ESI) $\mathrm{m} / z$ 273.0858 [calc'd for $\mathrm{C}_{14} \mathrm{H}_{13} \mathrm{~N}_{2} \mathrm{O}_{4}(\mathrm{M}+\mathrm{H})^{+} 273.0870$ ].

\subsubsection{2,2'-Bipyridine-4,5'-dicarboxylic acid (4c)}

Dimethyl 2,2'-bipyridine-4,5'-dicarboxylate (482 mg, 1.8 mmoles) and KOH (460 mg, 7.1 mmoles) were added to a vial. $\mathrm{MeOH}(9.0 \mathrm{~mL})$ was added to the vial, and the resulting reaction mixture was heated to $60^{\circ} \mathrm{C}$ until the starting material was consumed completely, as judged by TLC. The reaction mixture was cooled to room temperature and concentrated under reduced pressure. The crude product was dissolved in water $(20 \mathrm{~mL})$. The aqueous layer was washed with EtOAc $(1 \times 20 \mathrm{~mL})$, after which the product was precipitated from the aqueous layer by adjusting to $\mathrm{pH} 3-4$ with $1 \mathrm{M} \mathrm{HCl}$. After cooling to $4{ }^{\circ} \mathrm{C}$, the product was filtered, washed with water $(3 \times 5 \mathrm{~mL})$, and dried in vacuo to afford $\mathbf{4 c}(412 \mathrm{mg}, 95 \%)$ as an off-white solid with $\mathrm{mp}$ $>260{ }^{\circ}$ C. ${ }^{1} \mathbf{H}$ NMR (400 MHz, DMSO-d 6 , $\boldsymbol{\delta}$ ): 13.67 (bs, $\left.2 \mathrm{H}\right), 9.20$ (s, $\left.1 \mathrm{H}\right), 8.92$ (d, J = 4.8 Hz, 
$1 \mathrm{H}), 8.88(\mathrm{~s}, 1 \mathrm{H}), 8.54(\mathrm{~d}, J=8.0 \mathrm{~Hz}, 1 \mathrm{H}), 8.44(\mathrm{dd}, J=2.0,8.4 \mathrm{~Hz}, 1 \mathrm{H}), 7.93(\mathrm{~d}, J=4.8 \mathrm{~Hz}$,

$1 \mathrm{H}) ;{ }^{13} \mathrm{C}$ NMR (100 MHz, DMSO-d $\left.\mathbf{6}, \boldsymbol{\delta}\right):$ 166.5, 166.5, 158.0, 155.8 151.2, 150.8, 140.0, 139.0, 127.3, 124.2, 120.9, 120.7; HRMS (ESI) $m / z$ 243.0405 [calc'd for $\mathrm{C}_{12} \mathrm{H}_{7} \mathrm{~N}_{2} \mathrm{O}_{4}(\mathrm{M}-\mathrm{H})^{-}$ 243.0411].

\subsubsection{2,2'-Bipyridine-4,6' -dicarboxylic acid (4d)}

Dimethyl 2,2'-bipyridine-4,6'-dicarboxylate (75 mg, $0.28 \mathrm{mmoles})$ and $\mathrm{KOH}$ (80 mg, 1.12 mmoles $)$ were added to a vial. $\mathrm{MeOH}(8.0 \mathrm{~mL})$ was added to the vial, and the resulting reaction mixture was heated to $60{ }^{\circ} \mathrm{C}$ until the starting material was consumed completely, as judged by TLC. The reaction mixture was cooled and concentrated under reduced pressure, after which the crude product was dissolved in water $(2 \mathrm{~mL})$. The aqueous layer was washed with EtOAc $(1 \times 2$ $\mathrm{mL}$ ), after which the product was precipitated from the aqueous layer by adjusting to $\mathrm{pH} 3-4$ with $1 \mathrm{M} \mathrm{HCl}$. After cooling to $4{ }^{\circ} \mathrm{C}$, the product was filtered, washed with water $(3 \times 1 \mathrm{~mL})$, and dried in vacuo to afford $\mathbf{4 d}(49 \mathrm{mg}, 73 \%)$ as an off-white solid with $\mathrm{mp}>260{ }^{\circ} \mathrm{C}$. ${ }^{\mathbf{1}} \mathbf{H}$ NMR (400 MHz, DMSO-d $\left.\boldsymbol{d}_{6}, \boldsymbol{\delta}\right): 13.66(\mathrm{bs}, 2 \mathrm{H}), 8.94(\mathrm{~s}, 1 \mathrm{H}), 8.90(\mathrm{~d}, J=5.2 \mathrm{~Hz}, 1 \mathrm{H}), 8.62(\mathrm{dd}, J=$ 1.6, 7.6 Hz, $1 \mathrm{H}), 8.17(\mathrm{t}, J=7.6 \mathrm{~Hz}, 1 \mathrm{H}), 8.13(\mathrm{dd}, J=1.6,7.6 \mathrm{~Hz}, 1 \mathrm{H}), 7.92(\mathrm{dd}, J=1.6,4.8$ $\mathrm{Hz}, 1 \mathrm{H}) ;{ }^{13}$ C NMR (100 MHz, DMSO-d 6 , $\left.\boldsymbol{\delta}\right):$ 166.6, 166.4, 156.1, 155.0, 151.0, 148.7, 140.0, 139.4, 125.8, 124.1, 123.9, 120.4; HRMS (ESI) $m / z$ 243.0404 [calc'd for $\mathrm{C}_{12} \mathrm{H}_{7} \mathrm{~N}_{2} \mathrm{O}_{4}(\mathrm{M}-\mathrm{H})^{-}$ 243.0411].

\subsubsection{2,2' -Bipyridine-5,6'-dicarboxylic Acid (4f)}

Dimethyl 2,2'-bipyridine-5,6'-dicarboxylate (39 mg, $0.14 \mathrm{mmoles})$ and $\mathrm{KOH}$ (40 mg, 0.57 mmoles) were added to a vial. $\mathrm{MeOH}(4.0 \mathrm{~mL})$ was added to the vial, and the resulting reaction 
mixture was heated to $60^{\circ} \mathrm{C}$ until the starting material was consumed completely, as judged by TLC. The reaction mixture was cooled and concentrated under reduced pressure, after which the crude product was dissolved in water $(2 \mathrm{~mL})$. The aqueous layer was washed with EtOAc $(1 \times 2$ $\mathrm{mL}$ ), after which the product was precipitated from the aqueous layer by adjusting to $\mathrm{pH} 3-4$ with $1 \mathrm{M} \mathrm{HCl}$. After cooling to $4{ }^{\circ} \mathrm{C}$, the product was filtered, washed with water $(3 \times 1 \mathrm{~mL})$, and dried in vacuo to afford $\mathbf{4 f}(20 \mathrm{mg}, 57 \%)$ as an off-white solid with $\mathrm{mp}>260{ }^{\circ} \mathrm{C} .{ }^{\mathbf{1}} \mathbf{H}$ NMR (400 MHz, DMSO-d $\left.\boldsymbol{d}_{\mathbf{6}} \boldsymbol{\delta}\right): 13.47$ (bs, $\left.2 \mathrm{H}\right), 9.18(\mathrm{~d}, J=1.6 \mathrm{~Hz}, 1 \mathrm{H}), 8.68-8.64(\mathrm{~m}, 2 \mathrm{H}), 8.47$ (dd, $J=$ $2.0,8.0 \mathrm{~Hz}, 1 \mathrm{H}), 8.20-8.14$ (m, $2 \mathrm{H}) ;{ }^{13}$ C NMR (100 MHz, DMSO-d $\left.\boldsymbol{6}, \boldsymbol{\delta}\right): 166.5,166.3,158.0$, 154.6, 150.6, 148.7, 139.5, 138.8, 127.3, 126.0, 124.7, 121.3; HRMS (ESI) m/z 243.0414 [calc'd for $\left.\mathrm{C}_{12} \mathrm{H}_{7} \mathrm{~N}_{2} \mathrm{O}_{4}(\mathrm{M}-\mathrm{H})^{-} 243.0411\right]$.

\subsubsection{2. $N$-(Methoxyoxalyl)glycine ethyl ester}

HGlyOEt $\cdot \mathrm{HCl}$ (333 mg, 2.4 mmoles) and DMAP (29.1 mg, 0.24 mmoles) were added to a round-bottom flask. The flask was capped with a septum and purged with $\mathrm{N}_{2}(\mathrm{~g})$ ( $\sim 5$ times). DCM $(6 \mathrm{~mL})$ was added, and the reaction mixture was cooled in an ice bath. DIEA $(750 \mu \mathrm{L}$, 4.3 mmoles) and monomethyl oxalyl chloride (200 $\mu \mathrm{L}, 2.2$ mmoles) were added via syringe, and the reaction was stirred and allowed to come to room temperature. After $6 \mathrm{~h}$, the reaction mixture was quenched on ice by the dropwise addition of a saturated aqueous solution of ammonium chloride $(10 \mathrm{~mL})$. The organic layer was collected, and the aqueous layer was extracted with EtOAc $(3 \times 10 \mathrm{~mL})$. The combined organic extracts were dried over $\mathrm{Na}_{2} \mathrm{SO}_{4}(\mathrm{~s})$, and concentrated under reduced pressure to afford a crude yellow oil. The crude product was then purified by chromatography on silica (70\% v/v EtOAc in hexanes) to afford the title compound (416 mg, 92\%) as a white solid with mp 58.5-62.5 ${ }^{\circ} \mathrm{C} .{ }^{\mathbf{1}} \mathbf{H}$ NMR (400 $\left.\mathbf{M H z}, \mathbf{C D C l}_{3}, \delta\right): 7.65$ (bs, 1H), 
$4.23(\mathrm{q}, J=7.2 \mathrm{~Hz}, 2 \mathrm{H}), 4.11(\mathrm{~d}, J=5.6 \mathrm{~Hz}, 2 \mathrm{H}), 3.90(\mathrm{~s}, 3 \mathrm{H}), 1.28(\mathrm{t}, J=7.2 \mathrm{~Hz}, 3 \mathrm{H}) ;{ }^{13} \mathbf{C}$

NMR (100 MHz, $\mathbf{C D C l}_{3}, \delta$ ): 168.6, 160.4, 156.4, 61.9, 53.7, 41.5, 14.1; HRMS (ESI) $\mathrm{m} / z$

212.0535 [calc'd for $\mathrm{C}_{7} \mathrm{H}_{11} \mathrm{NO}_{5} \mathrm{Na}(\mathrm{M}+\mathrm{Na})^{+} 212.0530$ ].

\subsubsection{3. $N$-Oxalylglycine (2)}

$N$-(Methoxyoxalyl)glycine ethyl ester (100 mg, 0.53 mmoles) and $\mathrm{KOH}$ (88 mg, $1.6 \mathrm{mmoles})$ were added to a vial. $\mathrm{MeOH}(5.0 \mathrm{~mL})$ was added to the vial, and the resulting reaction mixture was heated to $60{ }^{\circ} \mathrm{C}$ until the starting material was consumed completely, as judged by TLC. The reaction mixture was cooled to room temperature and concentrated under reduced pressure. The crude product was dissolved in water $(2 \mathrm{~mL})$, and the $\mathrm{pH}$ of the resulting solution was adjusted to 3-4 with $1 \mathrm{M} \mathrm{HCl}$. The aqueous solution was concentrated under reduced pressure, and the residue was dissolved in boiling EtOAc. The solution was cooled, filtered, and concentrated under reduced pressure to a viscous oil. The oil was dissolved in a minimal amount of DCM, diluted with hexanes, and concentrated under reduced pressure. This procedure was repeated 3 times, after which the product was dried under high vacuum to afford $\mathbf{2}(77 \mathrm{mg}, 99 \%)$ as a white solid with mp 104.5-110.5 ${ }^{\circ} \mathrm{C} .{ }^{1} \mathbf{H}$ NMR (500 MHz, DMSO-d $\boldsymbol{~}_{\mathbf{6}} \boldsymbol{\delta}$ ): 14.03 (bs, $\left.1 \mathrm{H}\right), 12.76$ (bs, 1 H), $9.04(\mathrm{t}, J=6.0 \mathrm{~Hz}, 1 \mathrm{H}), 3.79(\mathrm{~d}, J=6.5 \mathrm{~Hz}, 2 \mathrm{H}) ;{ }^{13}$ C NMR (125 MHz, DMSO-d $\left.\boldsymbol{6}, \boldsymbol{\delta}\right)$ : 170.8, 162.1, 158.9, 41.4; HRMS (ESI) $m / z$ 165.0506 [calc'd for $\mathrm{C}_{4} \mathrm{H}_{9} \mathrm{~N}_{2} \mathrm{O}_{2}\left(\mathrm{M}+\mathrm{NH}_{4}\right)^{+}$ $165.0506]$.

\subsubsection{4. $N$-Benzyloxycarbonyl-(2S)-prolyl-(2S)-prolylglycine ethyl ester (CbzProProGlyOEt)}

$N$-Benzyloxycarbonyl-(2S)-prolyl-(2S)-proline (CbzProProOH, 967 mg, 2.8 mmoles), 
HGlyOEt $\cdot \mathrm{HCl}$ (428 mg, $3.1 \mathrm{mmoles}), \mathrm{EDC} \cdot \mathrm{HCl}(590 \mathrm{mg}, 3.1 \mathrm{mmoles})$, and HOBT (415 mg, 3.1 mmoles) were added to a round-bottom flask. The flask was capped with a septum and purged with $\mathrm{N}_{2}(\mathrm{~g})$ ( $\sim$ times). DMF (28 mL) and DIEA (1.9 mL, 11.2 mmoles) were added via syringe, and the reaction mixture was stirred at room temperature until the reaction was judged to be complete by TLC (approximately $48 \mathrm{~h}$ ). The reaction mixture was concentrated under reduced pressure, and the resulting residue dissolved in EtOAc $(50 \mathrm{~mL})$. The organic layer was washed with $5 \%$ w/v $\mathrm{KHCO}_{3}(2 \times 25 \mathrm{~mL}), 5 \% \mathrm{w} / \mathrm{v} \mathrm{KHSO}_{4}(2 \times 25 \mathrm{~mL})$, and brine $(1 \times 25 \mathrm{~mL})$. The combined organics were dried over $\mathrm{Na}_{2} \mathrm{SO}_{4}(\mathrm{~s})$ and concentrated under reduced pressure to a crude yellow oil. The crude product was then purified by chromatography on silica $(0-2 \% \mathrm{v} / \mathrm{v}$ $\mathrm{MeOH}$ in EtOAc) to yield the title compound $(755 \mathrm{mg}, 63 \%)$ as a pale yellow oil. ${ }^{\mathbf{1}} \mathbf{H}$ NMR (400 $\mathrm{MHz}, \mathrm{CDCl}_{3}$, mixture of 3 or more rotamers, integrations are approximate, $\left.\delta\right): 8.29(\mathrm{t}, J=$ $6.0 \mathrm{~Hz}, 0.7 \mathrm{H}), 7.40-7.20\left(\mathrm{~m}, 15.4 \mathrm{H}+\mathrm{CHCl}_{3}\right), 7.15-7.11(\mathrm{~m}, 0.4 \mathrm{H}), 5.94(\mathrm{t}, J=6.0 \mathrm{~Hz}, 0.1 \mathrm{H})$, $5.31(\mathrm{~d}, J=12.4 \mathrm{~Hz}, 0.1 \mathrm{H}), 5.18-4.93(\mathrm{~m}, 5.0 \mathrm{H}), 4.77(\mathrm{~d}, J=12.4 \mathrm{~Hz}, 0.1 \mathrm{H}), 4.69(\operatorname{app} \mathrm{dd}, J=$ 2.4, 8.0 Hz, 1.0 H), 4.54 (app dd, $J=4.0,4.0 \mathrm{~Hz}, 1.0 \mathrm{H}), 4.49-4.20$ (m, 3.4 H), 4.17-3.80 (m, $10.4 \mathrm{H}), 3.76-3.39(\mathrm{~m}, 10.0 \mathrm{H}), 3.31-3.23(\mathrm{~m}, 0.9 \mathrm{H}), 2.99(\operatorname{app} \mathrm{dd}, J=6.0,17.6 \mathrm{~Hz}, 0.1 \mathrm{H})$, 2.53 (app dd, $J=5.6,12.4 \mathrm{~Hz}, 0.7 \mathrm{H}), 2.35-1.65(\mathrm{~m}, 21.4 \mathrm{H}), 1.44-1.01(\mathrm{~m}, 9.6 \mathrm{H}) ;{ }^{13} \mathbf{C}$ NMR $\left(\mathbf{1 0 0} \mathbf{~ M H z}, \mathbf{C D C l}_{3}\right.$, mixture of 3 or more rotamers, $\delta$ ): 172.9, 172.5, 171.7, 171.6, 171.5, 171.4, 171.3, 169.7, 169.6, 169.3, 168.7, 155.2, 154.9, 154.0, 136.7, 136.5 (multiple signals), 129.0, 128.8, 128.6, 128.4 (multiple signals), 128.1 (2 signals), 127.9 (2 signals), 127.7 (multiple signals), 125.3, 67.3, 67.2, 67.1, 66.9, 61.2 (multiple signals), 61.1, 61.0, 59.7, 59.4, 58.5, 58.3 (multiple signals), 57.4, 47.7, 47.3 (2 signals), 47.1 (multiple signals), 46.9 (multiple signals), 46.7 (multiple signals), 41.5, 41.2, 40.5, 33.9, 31.2, 31.8, 30.4 (multiple signals), 29.4 (2 signals), 26.9, 26.5 (multiple signals), 25.7, 25.2 (multiple signals), 25.0, 24.7, 24.3, 23.7, 23.4, 22.1, 22.0, 
14.1 (2 signals); HRMS (ESI) $m / z$ 449.2374 [calc'd for $\mathrm{C}_{22} \mathrm{H}_{29} \mathrm{~N}_{3} \mathrm{O}_{6} \mathrm{Na}(\mathrm{M}+\mathrm{Na})^{+} 449.2395$ ].

\subsubsection{5. $N$-Dansylglycyl-(2S)-prolyl-(2S)-prolylglycine ethyl ester (dansylGlyProProGlyOEt)}

A suspension of CbzProProGlyOEt (755 mg, 1.8 mmoles) and $\mathrm{Pd} / \mathrm{C}(76 \mathrm{mg})$ in $\mathrm{MeOH}$ $(18 \mathrm{~mL})$ was stirred under an atmosphere of $\mathrm{H}_{2}(\mathrm{~g})$ for $3 \mathrm{~h}$. The reaction mixture was filtered through a pad of Celite ${ }^{\circledR}$ and then concentrated under reduced pressure to a pale yellow viscous oil (553 mg). The oil was dissolved in DCM (5.9 mL) and cooled to $0{ }^{\circ} \mathrm{C}$, after which dansylGlyOH (586 mg, 2.0 mmoles) and PyBroP ${ }^{\circledR}$ (973 mg, 2.3 mmoles) were added. The flask was capped with a septum and purged with $\mathrm{N}_{2}(\mathrm{~g})$. DIEA $(0.63 \mathrm{~mL})$ was added via syringe, and the reaction mixture was stirred at $0{ }^{\circ} \mathrm{C}$ for $5 \mathrm{~min}$. The reaction mixture was allowed to come to room temperature and stirred for an additional $6 \mathrm{~h}$. The reaction mixture was concentrated under reduced pressure, and the crude product was purified by chromatography on silica (2\% v/v $\mathrm{MeOH}$ in EtOAc) and HPLC (25-55\% v/v acetonitrile in $\mathrm{H}_{2} \mathrm{O}$ with $0.1 \% \mathrm{v} / \mathrm{v}$ TFA) to afford the title compound (950 mg, 92\%) as a yellow solid with mp 80.1-85.2 ${ }^{\circ} \mathrm{C} .{ }^{1} \mathbf{H}$ NMR (500 $\mathbf{~ M H z}$, $\mathrm{CDCl}_{3}$, mixture of 2 or more rotamers, integrations are approximate, $\left.\delta\right): 8.59(\mathrm{~d}, J=8.5 \mathrm{~Hz}$, $1.0 \mathrm{H}), 8.37(\mathrm{dd}, J=8.5,14.5 \mathrm{~Hz}, 1.1 \mathrm{H}), 8.25(\mathrm{ddd}, J=1.0,7.0,9.5 \mathrm{~Hz}, 1.0 \mathrm{H}), 8.20-8.14(\mathrm{~m}$, $0.7 \mathrm{H}), 7.65-7.55(\mathrm{~m}, 2.1 \mathrm{H}), 7.26(\mathrm{~d}, J=7.5 \mathrm{~Hz}, 1.0 \mathrm{H}), 7.18(\mathrm{t}, J=5.0 \mathrm{~Hz}, 0.7 \mathrm{H}), 5.76(\mathrm{dd}, J=$ 3.5, 5.0 Hz, 0.7 H), 5.67 (dd, $J=3.5,5.0 \mathrm{~Hz}, 0.6 \mathrm{H}), 4.58(\operatorname{app} \mathrm{dd}, J=2.5,8.0 \mathrm{~Hz}, 1.2 \mathrm{H}), 4.45$ (t, $J=6.5 \mathrm{~Hz}, 0.7 \mathrm{H}), 4.31(\mathrm{~d}, J=8.5 \mathrm{~Hz}, 0.6 \mathrm{H}), 4.24-4.13(\mathrm{~m}, 2.1 \mathrm{H}), 4.09-4.04(\mathrm{~m}, 0.8 \mathrm{H}), 3.94-$ 3.80 (m, 2.6 H), 3.74-3.61 (m, 2.3 H), 3.55-3.35 (m, 3.4 H), 2.97-2.95 (m, 4.9 H), 2.56 (app dd, $J=6.0,12.5 \mathrm{~Hz}, 0.7 \mathrm{H}), 2.36-2.31(\mathrm{~m}, 0.8 \mathrm{H}), 2.24-1.80(\mathrm{~m}, 11.9 \mathrm{H}), 1.33-1.26(\mathrm{~m}, 2.9 \mathrm{H}) ;{ }^{13} \mathbf{C}$ NMR (100 MHz, $\mathbf{C D C l}_{3}$, mixture of 2 or more rotamers, $\boldsymbol{\delta}$ ): 171.5, 171.4, 170.3, 169.7, 169.4, 
165.8, 165.4, 151.3, 150.9, 134.3, 134.2, 130.5, 130.4, 129.8 (2 signals), 129.7 (2 signals), 129.5, 129.4, 128.5, 128.4, 123.4, 123.3, 119.8 (multiple signals), 119.5 (multiple signals), 115.6 (2 signals), 61.4, 61.3, 61.1, 59.7, 59.1, 58.2, 47.2, 47.1, 46.6, 46.2, 45.6, 45.5, 44.6, 44.5, 41.5, 41.3, 31.8, 28.5, 28.4, 27.0, 25.2, 24.9, 24.5, 22.1, 14.2 (2 signals); HRMS (ESI) $\mathrm{m} / \mathrm{z}$ 610.2325 [calc'd for $\mathrm{C}_{28} \mathrm{H}_{37} \mathrm{~N}_{5} \mathrm{O}_{7} \mathrm{SNa}(\mathrm{M}+\mathrm{Na})^{+} 610.2306$ ].

\section{Acknowledgments}

This work was supported by Grant R01 AR044276 (NIH). J. D. V. was supported by Molecular Biosciences Training Grant T32 GM007215 (NIH) and a fellowship from the Department of Biochemistry at the University of Wisconsin-Madison. This study made use of the National Magnetic Resonance Facility at Madison, which is supported by Grant P41 GM103399 (NIH). The Micromass LCT ${ }^{\circledR}$ mass spectrometer was obtained with support from Grant CHE-9974839 (NSF).

\section{References and notes}

1. Shoulders, M. D.; Raines, R. T. Annu. Rev. Biochem. 2009, 78, 929.

2. Rosenbloom, J.; Castro, S. V.; Jimenez, S. A. Ann. Intern. Med. 2010, 152, 159.

3. Friedman, S. L.; Sheppard, D.; Duffield, J. S.; Violette, S. Sci. Transl. Med. 2013, 5, 1.

4. Provenzano, P. P.; Inman, D. R.; Eliceiri, K. W.; Knittel, J. G.; Yan, L.; Rueden, C. T.; White, J. G.; Keely, P. J. BMC Med. 2008, 6, 11.

5. Conklin, M. W.; Eickhoff, J. C.; Riching, K. M.; Pehlke, C. A.; Eliceiri, K. W.; Provenzano, P. P.; Friedi, A.; Keely, P. J. Am. J. Pathol. 2010, 178, 1221. 
6. Eisinger-Mathason, T. S.; Zhang, M.; Qiu, Q.; Skuli, N.; Nakazawa, M. S.; Karakasheva, T.; Mucaj, V.; Shay, J. E. S.; Stangenberg, L.; Sadri, N.; Puré, E.; Yoon, S. S.; Kirsch, D. G.; Simon, M. C. Cancer Discov. 2013, 3, 1190.

7. Gilkes, D. M.; Chaturvedi, P.; Bajpai, S.; Wong, C. C.; Wei, H.; Pitcairn, S.; Hubbi, M. E.; Wirtz, D.; Semenza, G. L. Cancer Res. 2013, 73, 3285.

8. Cox, T. R.; Bird, D.; Baker, A.-M.; Barker, H. E.; Ho, M. W.-Y.; Lang, G.; Erler, J. T. Cancer Res. 2014, 73, 1721.

9. Myllyharju, J.; Kivirikko, K. I. Trends Genet. 2004, 20, 33.

10. Abbreviations used: AKG, $\alpha$-ketoglutarate; BSA, bovine serum albumin; $\mathrm{CP} 4 \mathrm{H}$, collagen prolyl 4-hydroxylase; DTT, dithiothreitol; FAKGD, Fe(II)- and $\alpha$-ketoglutarate-dependent dioxygenase; Hyp, (2S,4R)-4 hydroxyproline; FIH, factor-inhibiting HIF; HIF, hypoxiainducible factor; JMJD2E, Jumonji domain-containing 2E; Pro, (2S)-proline; PHD, prolyl hydroxylase domain-containing protein; SAR, structure-activity relationship; Tris, tris(hydroxymethyl)aminomethane.

11. Gorres, K. L.; Raines, R. T. Crit. Rev. Biochem. Mol. 2010, 45, 106.

12. Berg, R. A.; Prockop, D. J. Biochem. Biophys. Res. Commun. 1973, 52, 115.

13. Myllyharju, J. Ann. Med. 2008, 40, 402.

14. Hausinger, R. P. Crit. Rev. Biochem. Mol. 2004, 39, 21.

15. Hieta, R.; Kukkola, L.; Permi, P.; Pirilä, P.; Kivirikko, K. I.; Kilpeläinen, I.; Myllyharju, J. J. Biol. Chem. 2003, 278, 34966.

16. Pekkala, M.; Hieta, R.; Bergmann, U.; Kivirikko, K. I.; Wierenga, R. K.; Myllyharju, J. J. Biol. Chem. 2004, 279, 52255. 
17. Anantharajan, J.; Koski, M. K.; Kursula, P.; Hieta, R.; Bergmann, U.; Myllyharju, J.;

Wierenga, R. K. Structure 2013, 21, 2107.

18. Rose, N. R.; Mcdonough, M. A.; King, O. N. F.; Kawamura, A.; Schofield, C. J. Chem. Soc. Rev. 2011, 40, 4364.

19. Myllylä, R.; Tuderman, L.; Kivirikko, K. I. Eur. J. Biochem. 1977, 80, 349.

20. Günzler, V.; Hanauske-Abel, H. M.; Myllylä, R.; Mohr, J.; Kivirikko, K. I. Biochem. J. 1987, $242,163$.

21. Vasta, J. D.; Higgin, J. J.; Kersteen, E. A.; Raines, R. T. Bioorg. Med. Chem. Lett. 2013, 21, 3597.

22. Majamaa, K.; Hanauske-Abel, H. M.; Günzler, V.; Kivirikko, K. I. Eur. J. Biochem. 1984, $138,239$.

23. Dowell, R. I.; Hadley, E. M. J. Med. Chem. 1992, 35, 800.

24. Franklin, T. J.; Hales, N. J.; Johnstone, D.; Morris, W. B.; Cunliffe, C. J.; Millest, A. J.; Hill, G. B. Biochem. Soc. Trans. 1991, 19, 812.

25. Hales, N. J.; Beattie, J. F. J. Med. Chem. 1993, 36, 3853.

26. Campeau, L.-C.; Rosseaux, S.; Fagnou, K. J. Am. Chem. Soc. 2005, 127, 18020.

27. Campeau, L.-C.; Stuart, D. R.; Leclerc, J.-P.; Bertrand-Laperle, M.; Villemure, E.; Sun, H.Y.; Lasserre, S.; Guimond, N.; Lecavallier, M.; Fagnou, K. J. Am. Chem. Soc. 2009, 131, 3291.

28. Duric, S.; Tzschucke, C. C. Org. Lett. 2011, 13, 2310.

29. Hanlon, D. P.; Watt, D. S.; Westhead, E. W. Anal. Biochem. 1966, 16, 225.

30. Fischer, B. E.; Häring, U. K.; Tribolet, R.; Sigel, H. Eur. J. Biochem. 1979, 94, 523.

31. Kersteen, E. A.; Higgin, J. J.; Raines, R. T. Protein Express. Purif. 2004, 38, 279. 
32. Hewitson, K. S.; Schofield, C. J.; Ratcliffe, P. J. Methods Enzymol. 2007, 435, 25.

33. Gibson, D. G. Methods Enzymol. 2011, 498, 349.

34. Job, P. Annali di Chimica Applicata 1928, 9.

35. Huang, C. Y. Methods Enzymol. 1982, 87, 509.

36. Myllyharju, J.; Kivirikko, K. I. EMBO J. 1997, 16, 1173. 
Table 1

Iron-binding parameters of bipyridine ligands

\begin{tabular}{cccc}
\hline Compound $^{\lambda_{\text {max }}} \begin{array}{c}\text { of Complex Stoichiometry } \\
(\mathrm{nm})^{a}\end{array}$ & $\begin{array}{c}\mathrm{Fe}_{20}-\mathrm{EC}_{50} \\
(\text { Ligand:Fe })^{b}\end{array}$ & $(\mu \mathrm{M})^{c}$ \\
\hline $\mathbf{1}$ & 523 & $3: 1$ & $43 \pm 2$ \\
$\mathbf{4 a}$ & $\mathrm{ND}^{d}$ & - & - \\
$\mathbf{4 b}$ & 541 & $3: 1$ & $38 \pm 1$ \\
$\mathbf{4 c}$ & 553 & $3: 1$ & $78 \pm 2$ \\
$\mathbf{4 d}$ & 559 & $2: 1$ & $26 \pm 1$ \\
$\mathbf{4 e}$ & 566 & $3: 1$ & $112 \pm 3$ \\
$\mathbf{4 f}$ & 566 & $2: 1$ & $27 \pm 1$ \\
$\mathbf{4 g}$ & $\mathrm{ND}^{d}$ & - & - \\
\hline
\end{tabular}

${ }^{a}$ Determined by spectrophotometry.

${ }^{b}$ Determined by Job's method. ${ }^{34,35}$

${ }^{c}$ Determined by titration of $20 \mu \mathrm{M} \mathrm{FeSO}_{4}$. Values are the mean $( \pm S E)$ of three replicates.

${ }^{d}$ Not detected. 
Table 2

Inhibition constants for $\mathrm{CP} 4 \mathrm{H}$

\begin{tabular}{ccc}
\hline Compound & $\mathrm{IC}_{50}(\mu \mathrm{M})^{a}$ & $K_{\mathrm{i}}(\mu \mathrm{M})^{b}$ \\
\hline 3b & $15 \pm 1$ & $2.6 \pm 0.2$ \\
$\mathbf{4 c}$ & $1.2 \pm 0.1$ & $0.20 \pm 0.02$ \\
$\mathbf{4 e}$ & $0.84 \pm 0.08$ & $0.14 \pm 0.01$ \\
\hline
\end{tabular}

${ }^{a}$ Interpolated from dose-response curves.

Values are the mean $( \pm S E)$ of three replicates.

${ }^{b}$ Estimated with the Cheng-Prusoff equation.

Values are the mean $( \pm S E)$ of three replicates. 


\section{Scheme 1}
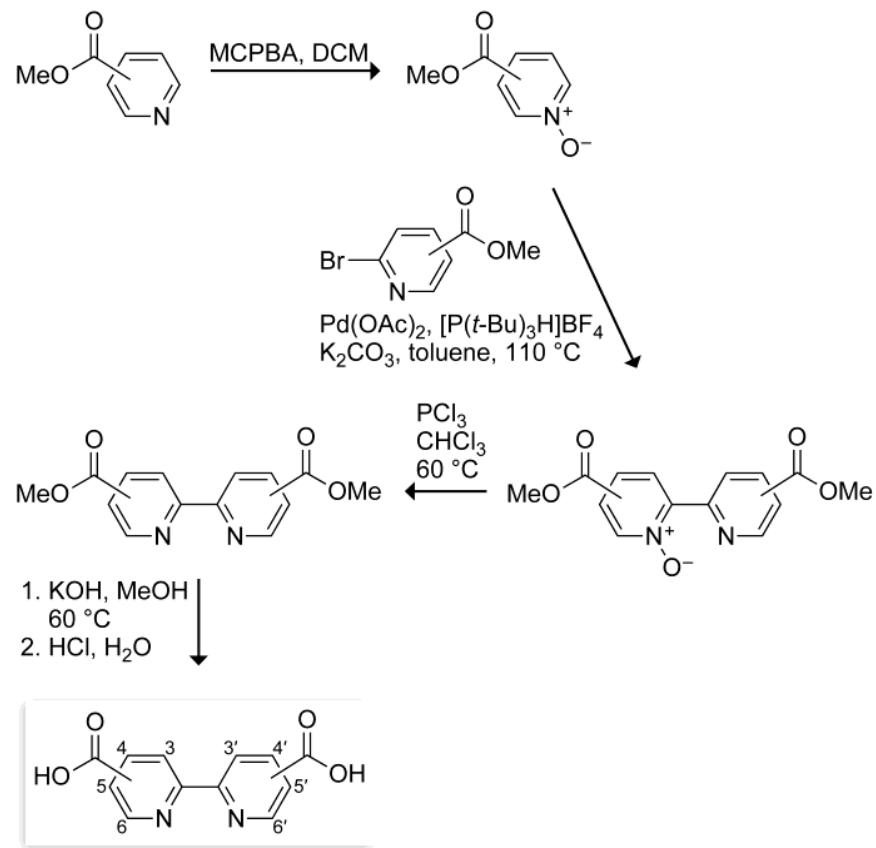


\section{FIGURE LEGENDS}

Figure 1. The reaction catalyzed by CP4Hs. In an Fe(II)- and AKG-dependent manner, CP4Hs catalyze the hydroxylation of specific Pro residues in collagenous peptides to form Hyp residues. The model peptide substrate used herein is dansylGlyProProGlyOEt, which is hydroxylated to form dansylGlyProHypGlyOEt.

Figure 2. Examples of known $\mathrm{CP} 4 \mathrm{H}$ inhibitors. Like most FAKGDs, $\mathrm{CP} 4 \mathrm{Hs}$ are inhibited by iron chelators (like 1) and simple AKG mimics (like 2, 3a, and 3b).

Figure 3. Structure of bipyridinedicarboxylates $(\mathbf{4 a}-\mathbf{4 g})$ and a bipyridinecarboxylate (5) examined in this work.

Figure 4. Inhibition of human $\mathrm{CP} 4 \mathrm{H} 1$ in vitro by 2,2'-bipyridinedicarboxylates. (A) To mitigate the effect of iron sequestration, all compounds were initially screened at a concentration of $10 \mu \mathrm{M}$ in the presence of excess Fe(II) as described in the Experimental Procedures section. Relative activity values are reported as the mean $( \pm S E)$ of three independent experiments. (B) Dose-response curves for the most potent inhibitors identified in panel A were determined as described in the Experimental Procedures section. Individual points represent the mean $( \pm \mathrm{SE})$ of three independent experiments. Data were fitted to the dose-response equation to determine $\mathrm{IC}_{50}$ values. 
Figure 5. Lineweaver-Burke analyses for inhibition of human CP4H1 $\mathbf{4 c}$ and $4 \mathbf{e}$. LineweaverBurke plots for (a) $\mathbf{4 c}$ and (b) $\mathbf{4 e}$ suggest competitive inhibition with respect to the AKG cosubstrate, as evidenced by the intersecting patterns that converge on the ordinate and linearity in the slope replots (shown below the corresponding Lineweaver-Burke plot).

The rate of $\mathrm{CP} 4 \mathrm{H}$ catalysis with increasing AKG concentration $(18-100 \mu \mathrm{M})$ was determined in the presence of fixed inhibitor concentrations (specified above) as described in the Experimental Procedures section. Individual points represent the mean $( \pm S E)$ of three independent experiments.

Figure 6. Inhibition of human PHD2 in vitro by 2,2'-bipyridinedicarboxylates. All compounds were screened at a concentration of $10 \mu \mathrm{M}$ in the presence of excess $\mathrm{Fe}(\mathrm{II})$ as described in the Experimental Procedures section. Relative activity values are reported as the mean $( \pm S E)$ of three independent experiments.

Figure 7. Schematic models of 2,2'-bipyridinedicarboxylate complexes with human $\mathrm{CP} 4 \mathrm{H} 1$ and human PHD2. (A) Our data suggests that human CP4H1 can bind two different 2,2'-bipyridinedicarboxylate geometries in the conventional AKG binding mode, where the enhanced potency of these inhibitors stems from additional enzymic interactions in the distal active site, which has yet to be characterized. Fe(II) is likely chelated by Asp414, His412, and His483. ${ }^{36}$ (B) Unlike CP4H, PHD2 accommodates only $4 \mathbf{c}$ in the AKG binding pocket. That finding and the similar potency of this compound compared to simple AKG mimics (e.g., 2 and 3a) are consistent with the formation of hydrogen bonds between the second carboxyl group and solvent. Fe(II) is chelated by Asp315, His313, and His374. ${ }^{18}$ 
Figure 1
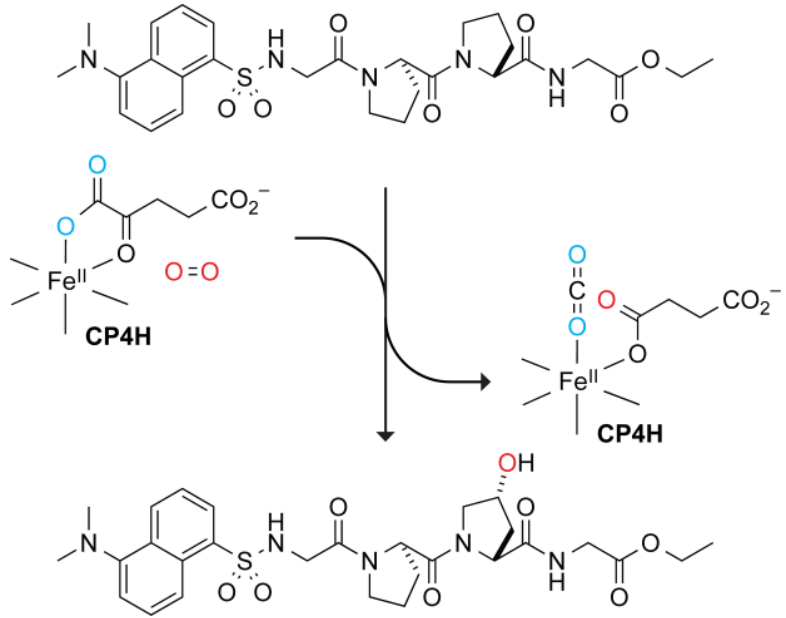


\section{Figure 2}
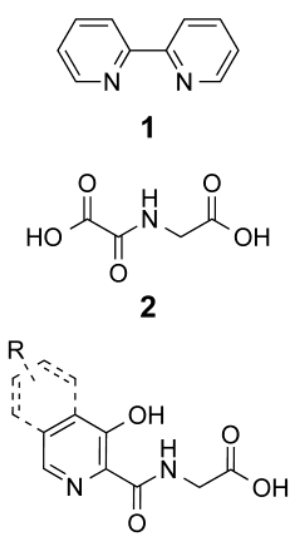

2-heterocyclic glycinamides
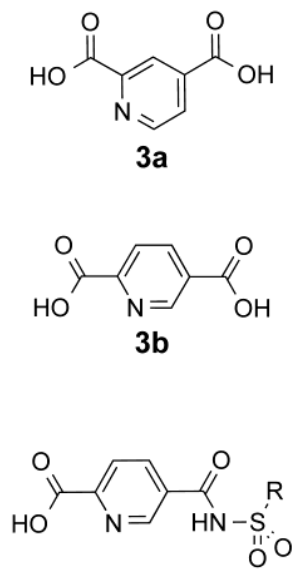

$\mathrm{N}$-acylsulfonamides 
Figure 3
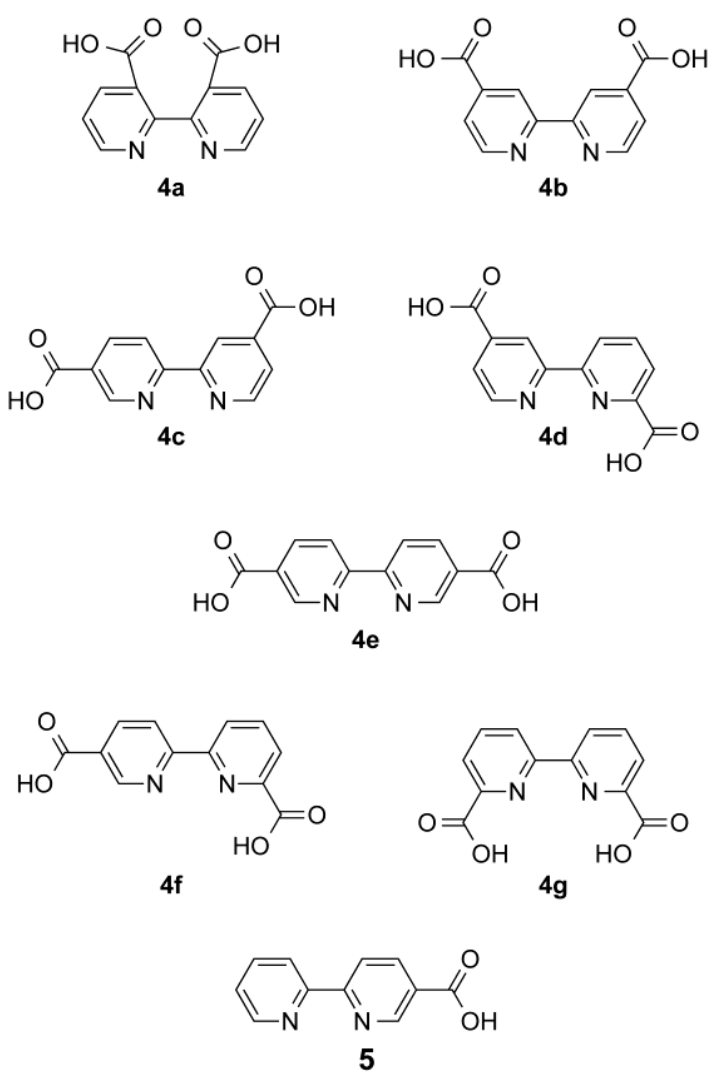
Figure 4
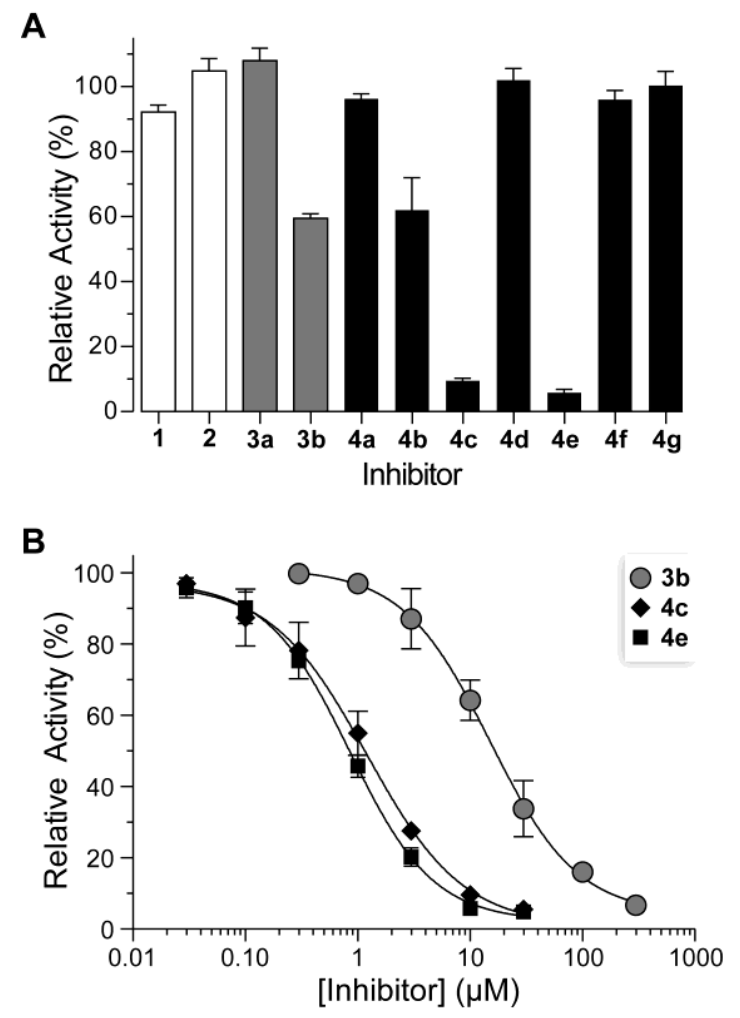


\section{Figure 5}

A
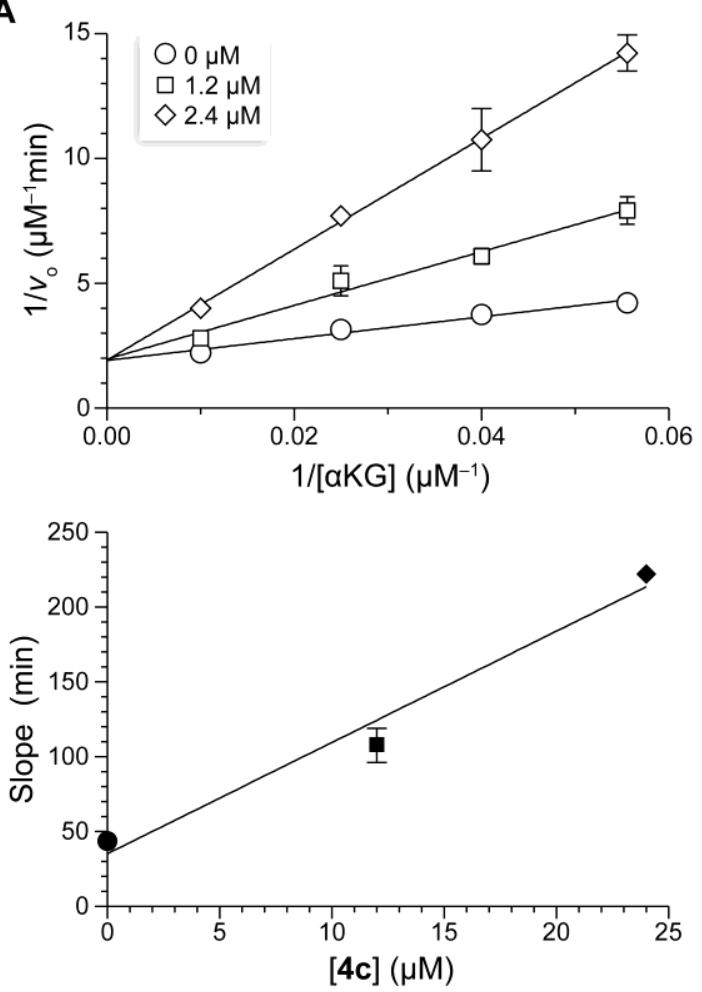

B
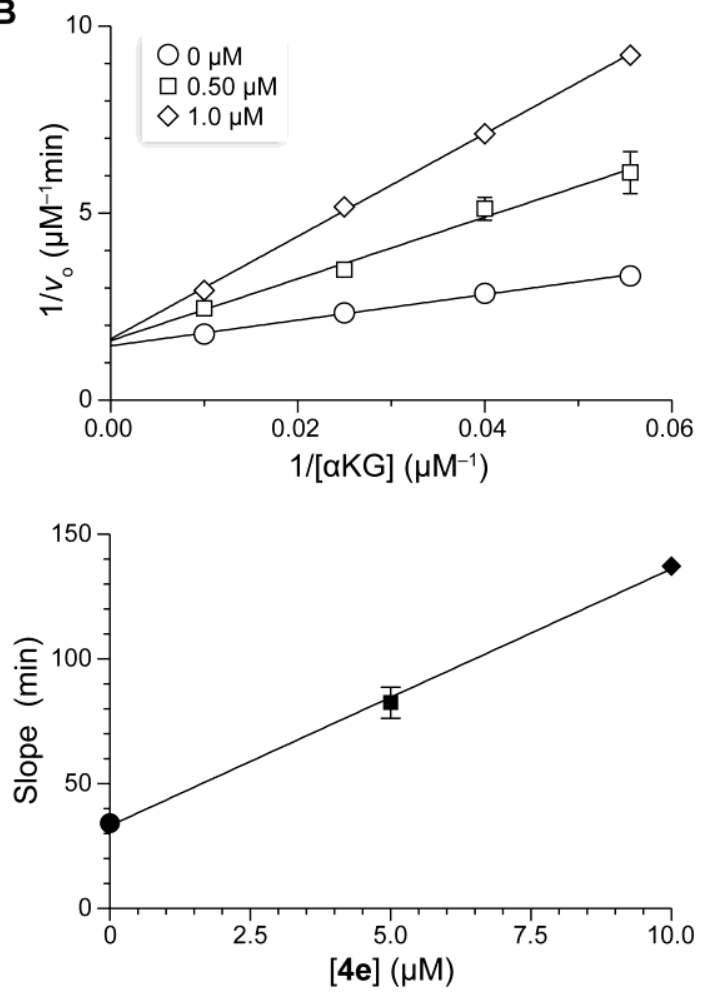
Figure 6

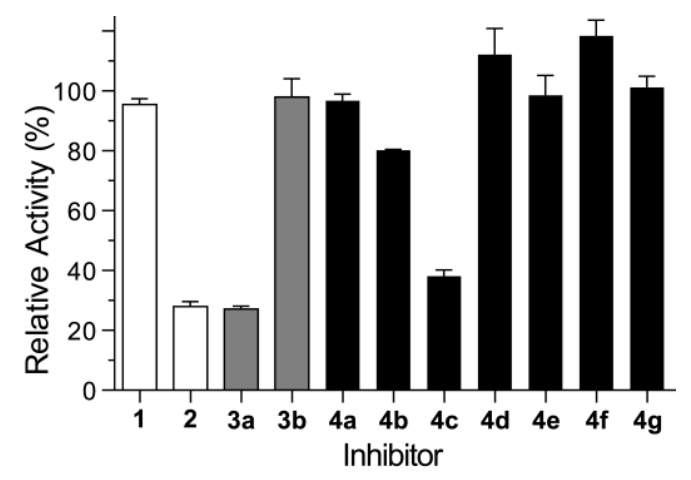




\section{Figure 7}

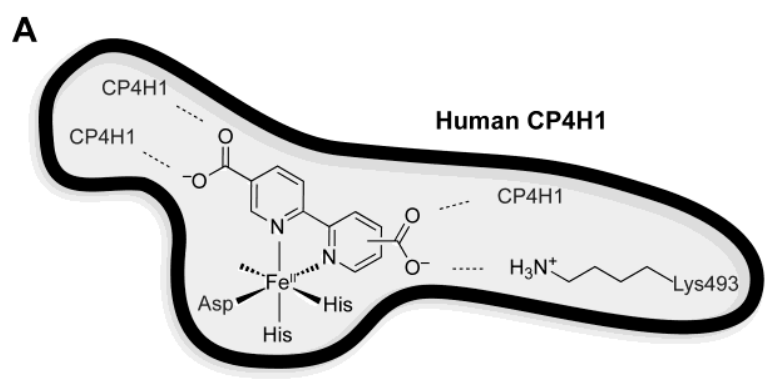

B

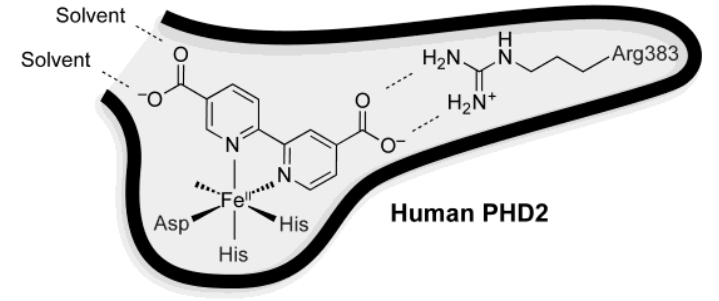


Graphical Abstract

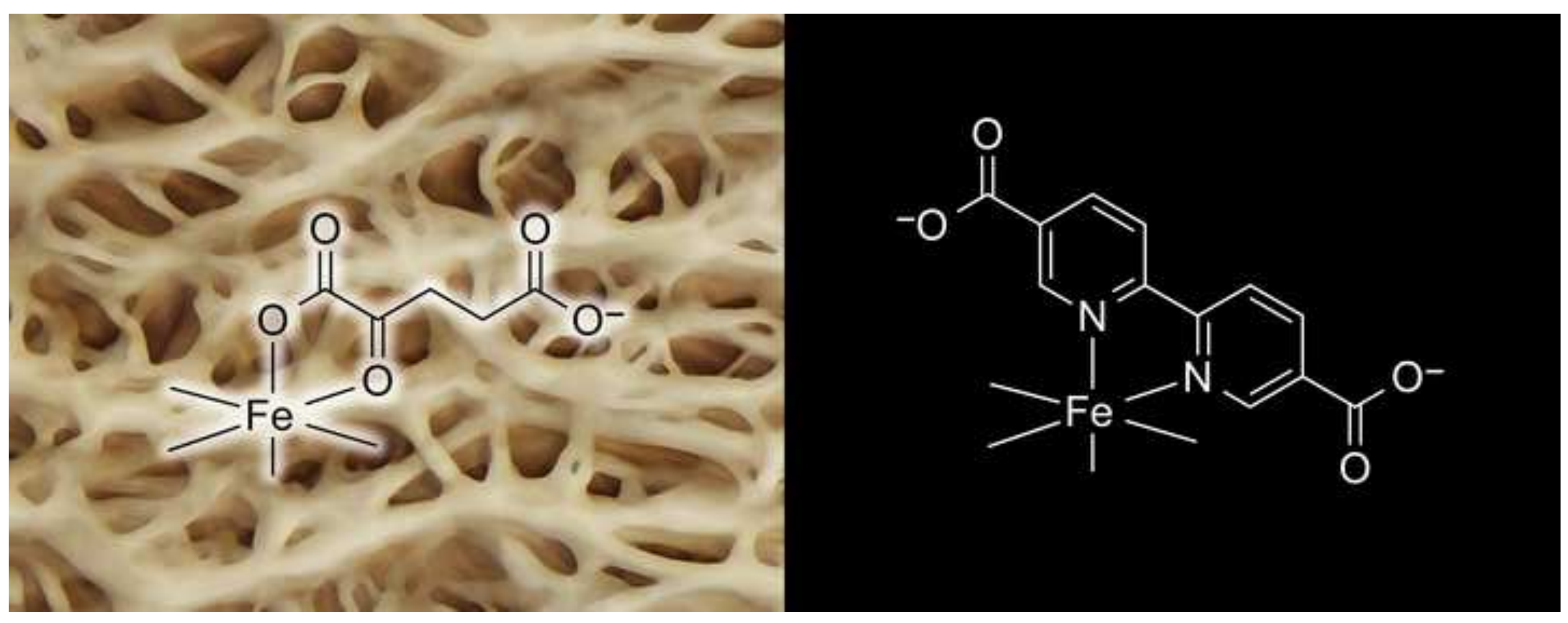

